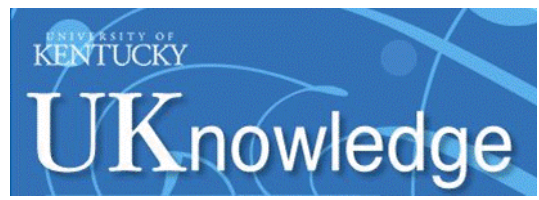

University of Kentucky

UKnowledge

\title{
Developmental Origins of Cardiovascular Disease: Impact of Early Life Stress in Humans and Rodents
}

\author{
Margaret O. Murphy \\ University of Kentucky, maggie.murphy@uky.edu \\ Dianne M. Cohn \\ University of Kentucky, dmco223@uky.edu \\ Analia S. Loria \\ University of Kentucky, analia.loria@uky.edu
}

Follow this and additional works at: https://uknowledge.uky.edu/pharmacol_facpub

Part of the Behavior and Behavior Mechanisms Commons, Cardiovascular Diseases Commons, and the Pharmacology, Toxicology and Environmental Health Commons

Right click to open a feedback form in a new tab to let us know how this document benefits you.

\section{Repository Citation}

Murphy, Margaret O.; Cohn, Dianne M.; and Loria, Analia S., "Developmental Origins of Cardiovascular Disease: Impact of Early Life Stress in Humans and Rodents" (2017). Pharmacology and Nutritional Sciences Faculty Publications. 87.

https://uknowledge.uky.edu/pharmacol_facpub/87

This Article is brought to you for free and open access by the Pharmacology and Nutritional Sciences at UKnowledge. It has been accepted for inclusion in Pharmacology and Nutritional Sciences Faculty Publications by an authorized administrator of UKnowledge. For more information, please contact UKnowledge@lsv.uky.edu. 
Developmental Origins of Cardiovascular Disease: Impact of Early Life Stress in Humans and Rodents

\section{Digital Object Identifier (DOI)}

https://doi.org/10.1016/j.neubiorev.2016.07.018

\section{Notes/Citation Information}

Published in Neuroscience \& Biobehavioral Reviews, v. 74, part B, p. 453-465.

(C) 2016 Elsevier Ltd. All rights reserved.

This manuscript version is made available under the CC-BY-NC-ND 4.0 license https://creativecommons.org/licenses/by-nc-nd/4.0/.

The document available for download is the author's post-peer-review final draft of the article. 


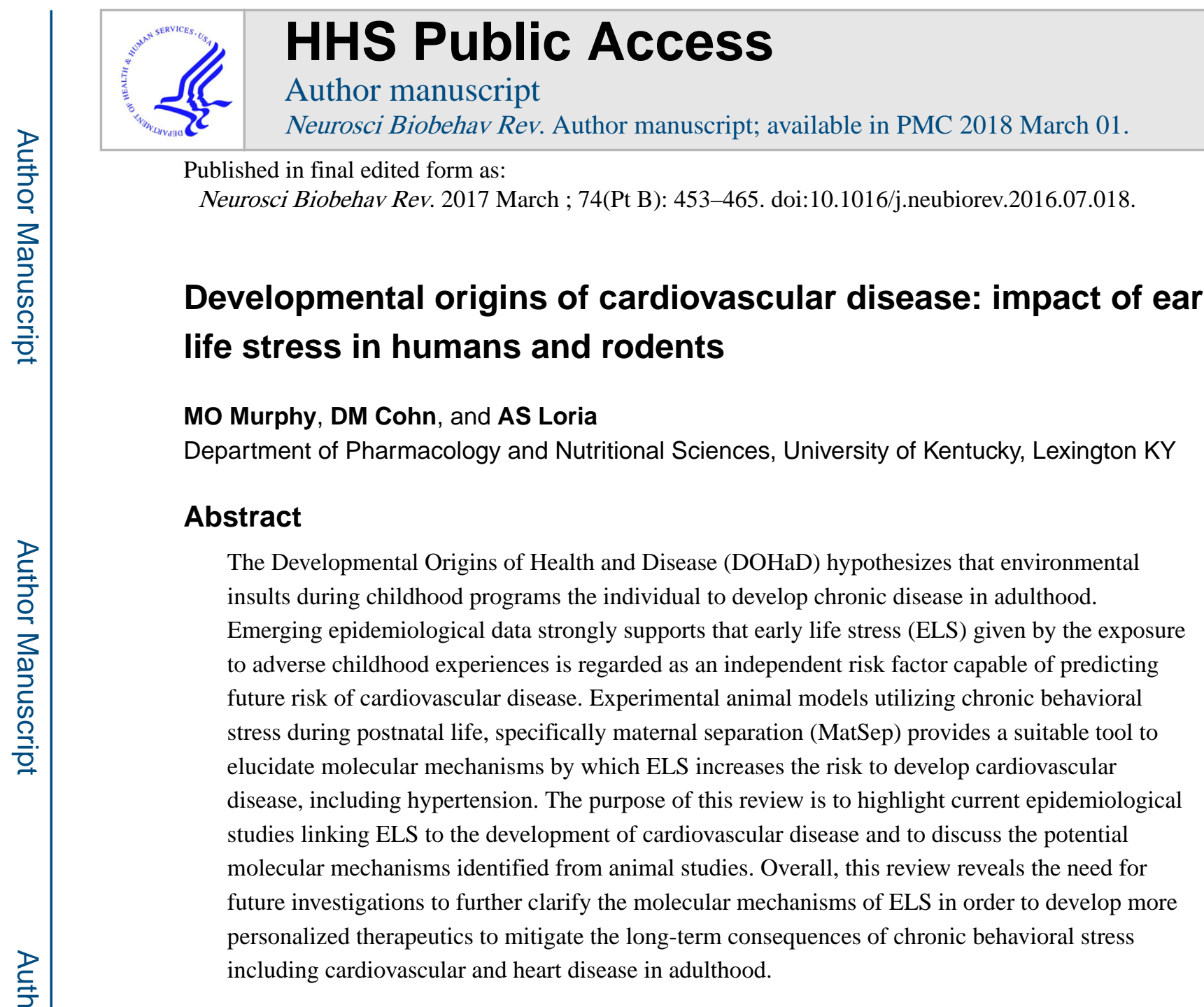

\section{Keywords}

early life stress; adverse childhood experiences; cardiovascular risk; hypertension; maternal separation

\section{Introduction}

Early life stress (ELS) is known to increase the risk of psychiatric disorders and health risk behaviors including smoking, overeating, and substance abuse (Danese et al., 2009; Dong et al., 2004; Freedman et al., 2007). In the last two decades a growing number of clinical studies demonstrated that exposure to ELS serves as an independent risk factor for the development of chronic disease. Therefore, ELS has been proven as a robust predictor of the

Correspondence to: Analia S. Loria, PhD., FAHA, Assistant Professor, University of Kentucky, Department of Pharmacology and Nutritional Sciences, 900 S. Limestone Street, 562 C.T. Wethington Building, Lexington, KY 40536-0200, Phone: 859-218-1414, Fax: 859-257-3646, analia.loria@uky.edu.

Disclosures

None

Publisher's Disclaimer: This is a PDF file of an unedited manuscript that has been accepted for publication. As a service to our customers we are providing this early version of the manuscript. The manuscript will undergo copyediting, typesetting, and review of the resulting proof before it is published in its final citable form. Please note that during the production process errors may be discovered which could affect the content, and all legal disclaimers that apply to the journal pertain. 
risk for ischemic heart disease, cardiovascular disease, stroke, respiratory disease, diabetes and cancer (Alastalo et al., 2013; Joung et al., 2014; Low et al., 2009; Murgatroyd and Spengler, 2011; Parrish et al., 2013; Romans et al., 2002.; Slopen et al., 2012; Su et al., 2015; Vaiserman, 2014; Weder et al., 2014; Yang et al., 2013).

Although it is well known that exposure to ELS influences the biological responsiveness to future stress, the physiological and molecular mechanisms are not completely understood. There is substantial evidence that stress delivered by parents and other caregivers can affect a child's developing brain architecture and chemistry increasing the susceptibility to stressrelated disorders later in life (Carroll et al., 2013; Furukawa et al., 1999). This finding has been mirrored in animal models as well (Caldji et al., 1998; McEwen et al., 2015; Sapolsky and Meaney, 1986; Weaver et al., 2004). Stress responses include activation of a variety of hormonal and neurochemical systems across the body. In this regard, the hypothalamicpituitary-adrenocortical (HPA) system and the sympathetic nervous system (SNS) have received special attention. In addition, it has been shown that several vasoactive peptides such as vasopressin, endothelin-1 and angiotensin II are released secondary to behavioral stimuli, exerting amplificatory effects in cardiovascular reactivity (Aguilera and RabadanDiehl, 2000; Loria et al, 2010b; Mangiafico et al., 2002; Mayorov, 2011; Spieker et al., 2002; Treiber et al., 2000). Cardiovascular reactivity reflects an enhanced response in blood pressure, heart rate or other hemodynamic parameters to secondary stressors (Manuck \& Krantz, 1985). Importantly, it has been shown that individuals showing exaggerated cardiovascular responses linked to acute and/or chronic behavioral stress may be at higher risk for the development of cardiovascular disease including hypertension and coronary artery disease than those individuals that do not display this positive correlation. (Beutel et al., 2014a; Carrol et al. 2013; Ginty et al., 2016; Spartano et al., 2014). Moreover, the impaired post-stress recovery of blood pressure has been shown blunted in patients with a history of ELS (Evans et al., 2013).

In this review, we will provide an overview of epidemiological data linking ELS to the development of cardiovascular disease. Also, we will discuss the use of animal models as a tool to mimic the effects of ELS on key components of the cardiovascular regulation in order to analyze the underlying molecular mechanisms leading to chronic disease.

\section{From allostasis to toxic stress}

Not all stress is harmful. In a child, when the stress response is activated in the context of a supportive psychosocial environment (e.g. supportive relationship with parents), these physiological effects are balanced and return to basal levels (National Scientific Council on the Developing Child, 2004). As a result of this adaptive process, there is a development of healthy stress response or even resilience to stress (Daskalakis et al., 2013; Smith and Carlson, 1997; Steptoe et al., 2009). Traumatic events can also be tolerable, or even beneficial, depending on the duration, intensity, and timing of the stressful experience, as well as its context (Shonkoff and Garner, 2012). Since a child's ability to cope with stress in the early years has consequences for physical and mental health throughout life, understanding the origin and complexity of different types of stress responses to early adverse experiences can help us make better conclusions about the type of interventions 
needed to potentially reduce the risk for later negative physiological outcomes in each patient.

In animal models, positive experiences after weaning, such as being exposed to an environment rich in opportunities for exploration and social play have been shown to compensate to some degree for the negative behavioral consequences of prenatal stress and postnatal neglect (Reynolds et al., 2010; Zanca et al., 2015). This compensation involves adaptive changes in both the architecture and the chemistry of the developing brain. However, the brain is not infinitely plastic. Some stress-related effects (e.g., reduced glucocorticoid (GR) in the hippocampus) may lead to permanent changes in the adult phenotype (Filipović et al., 2005). For instance, chronic stress can increase anxiety and decrease memory and cognitive flexibility (Marin et al., 2011). From the point of view of therapeutic approaches, it is promising that these changes in neuronal circuitry are reversible in a healthy, resilient brain (Russo et al., 2012).

Allostasis refers to the body's response to toxic stress such as loud noise, hostility, fatigue, isolation, hunger, and threats to safety (Sterling and Eyer, 1981). Allostatic load is the "wear and tear on the body" and results when these allostatic systems including the HPA axis, metabolic pathways, and immune system are hyperactivated after a stressful event. The concept of allostatic load has been described to explain these adverse health outcomes in adulthood. The autonomic nervous system and HPA axis lead to adaptation, coined as "allostasis" by Sterling and Eyer when the body responds to stress (Sterling and Eyer, 1981); however, these responses to stress can have long-term deleterious effects on the body (McEwen, 1998). The hippocampus plays a key role in perception of stress or the level of allostatic load that an individual will experience (McEwen, 1998). According to the allostatic load hypothesis, ELS induce biological changes that modify the maturation of allostatic systems. Frequent or chronic activation of allostatic systems may cause allostatic overload, thereby resulting in chronic disease later in life (Katz et al., 2012; Misra et al., 2013).

Yet, when the environmental insults overwhelm the individual's capacity to adapt to the stressor, it becomes harmful and toxic. Toxic stress is defined as "the excessive or prolonged activation of physiologic stress response systems in the absence of buffering protection afforded by stable responsive relationships (Shonkoff and Garner, 2012)". It has been shown that toxic stress can disrupt the developing brain, thereby influencing health outcomes decades later (McEwen, 2006). Examples of toxic stress include significant adversity such as poverty, abuse, neglect, neighborhood violence, or the substance abuse or mental illness of a caregiver. Table 1 shows the findings from a large number of cohort studies that were able to identify biomarkers associated with higher cardiovascular risk in response to the exposure to different sources of ELS. Overall, the intensity, length and number of adverse factors seem to have an additive effect in the physiological outcomes analyzed and certainly predict an enhanced risk to develop cardiovascular disease during the adult life (Dong et al., 2004; Felitti et al., 1998). 


\section{Early life stress and cardiovascular disease: what the cohort studies revealed}

Numerous clinical studies link ELS to a broad range of negative health outcomes. The association between ELS and psychosis, depression, anxiety, and attempted suicide are typically studied. However, more recent attention has been brought to ELS as an independent risk factor for hypertension, obesity, substance abuse, smoking as well, which are major contributors in the development of cardiovascular disease (CVD) and type 2 diabetes (Brent and Silverstein, 2013; Luecken, 1998; Varese et al., 2012).

A seminal paper from Dong et al. first described the relationship between ELS, given by exposure to adverse childhood experiences (ACEs). Dong's group reported a dose-response relationship of ACEs to ischemic heart disease (Dong et al., 2004). In addition, children raised in low socioeconomic status households under stressful conditions have developed elevated blood pressure over time and increased vascular reactivity to stress (Carroll et al., 2013). In the Bogalusa Heart and other studies, those individuals with the greatest trajectory of blood pressure increase during childhood and adolescence had severalfold higher prevalence of hypertension and increased mortality as adults (Oikonen et al., 2011). Further evidence has been provided by a natural human event involving Finnish children separated from their parents during World War II revealed that those children separated at ages 4-7 years had systolic blood pressure approximately $9 \mathrm{mmHg}$ higher as adults than nonseparated individuals while those separated at different ages did not have significant difference in systolic blood pressure. Notably, Woodall and Matthews have reported that boys aged 8-17 (but not girls) from unsupportive families have stronger heart rate responses during a series of laboratory stressors (Matthews et al., 1990).

More recently, findings from the Georgia Stress and Heart (GSH) study revealed that individuals who were exposed to multiple ACEs display a greater increase in blood pressure levels in young adulthood compared to control individuals in a 23-year follow up period ( $\mathrm{Su}$ et al., 2015). This effect was present independent of BMI and the authors suggest that increased levels of endothelin-1 (Su et al., 2014) may be a potential mechanism linking ELS and the development of stress-induced elevations in blood pressure.

In a situation of extreme adversity, starvation plays a detrimental role in terms of programming for adult disease. Several epidemiological reports following birth cohorts exposed to famine (Dutch 1944-1945; Ukraine 1932-1933; Chinese Famine 1959-1961) reveal that exposure to starvation conditions in early life induce metabolic disease in adulthood including a cluster of metabolic syndrome biomarkers such as dyslipidemia, hypertension, obesity, type 2 diabetes, and cardiovascular morbidity (Vaiserman, 2014), all risks factor for coronary artery disease. In sum, these studies (also see Table 1) show that there is a highly sensitive window of life to induce permanent changes in the cardiovascular system (Anda et al., 2009; Miller et al., 2011). 


\section{Maternal Separation as an animal model to mimic childhood adversity}

There is growing evidence of comorbidities for anxiety, depression and CVD (Davidson, 2012; Glassman, 2007; Halaris, 2009; Huffman et al., 2013; Ruo et al., 2003), challenging the current research community to provide animal models in order to investigate the mechanisms by which behavioral stress during the developmental stages of life influences adult cardiovascular function. Multiple models of perinatal programming have shown to induce a significant increase in blood pressure in the offspring. These models include restraint stress during gestation days 15 to 21 , maternal protein deprivation, and glucocorticoid exposure via dexamethasone administration during gestation (Harris and Seckl, 2011; Igosheva et al., 2004; Mizuno et al., 2013). However, maternal separation (MatSep) and similar models of chronic behavioral stress seem to induce a "first hit" effect that does not change the baseline cardiovascular parameters in young adult rodents, but primes the physiological systems to overreact in response to a secondary stressor or "second hit."(Ho et al., 2016; Loria et al., 2010b; Sanders and Anticevic, 2007).

MatSep is a well-established model of ELS in which neonatal pups are separated from their mothers for 3 hours a day from postnatal day 2 to 14 (Lehmann et al., 2000; Lippmann et al., 2007; Loria et al., 2010b).

Originally, MatSep has been widely used in the psycho-neuroendocrinology field to assess its long lasting effects on behavioral responses. These results demonstrated that animals exposed to MatSep develop depressive-like behavior and anxiety in adult life.

MatSep has been most widely performed in rats and mice, but also different species including non-human primates, rabbits, pigs, guinea-pig, birds (see review Loria et al., 2013). The variety of species, length of separation protocol and the period of life for the analysis of the outcomes (e.g. juvenile vs. adult) have resulted in numerous derangements described in the literature. However, rodents are the most consistently used models perhaps due to their similar responses to stress in comparison to humans as well as availability, costeffectiveness and the possibility for genetic manipulation in the investigation of basic molecular mechanisms. Previously, we have reported impaired blood pressure regulation in rats exposed to 3 hours of maternal separation daily from postnatal day 2-14 (Loria et al., 2013a). Within a murine model, MatSep with early weaning consists of separating the litters for 4 hours per day during postnatal days $2-5$ followed by 8 hours per day from postnatal day 6-16 with weaning at day 17 induces vascular endothelial dysfunction and superoxide production thus increasing cardiovascular risk (Ho et al., 2016).

MatSep in rodents is ideally suited to model ELS in humans because of the strong parallels in long-term neuronal and cardiovascular outcomes. For instance, many symptomatic characteristics associated with the consequences of emotional trauma have been shown to impact the cardiovascular system of rodents in a similar fashion to the observed in adult humans (Beutel et al., 2014; Loria et al., 2013a; Mascitelli et al., 2006; Rahman et al., 2013; Sanders and Anticevic, 2007). Rodent models mimic the behavioral outcome of ELS in humans such as anxiety and depression (Heim and Binder, 2012; Schmidt et al., 2011; Uchida et al., 2010). Similar to humans, rodents exposed to MatSep have increased risk of 
developing hypertension and cardiovascular pathologies in adulthood (Loria et al., 2013a; Loria et al., 2010b). Interestingly, MatSep in mouse has been a useful paradigm to model childhood neglect as well (Fabricius et al., 2008; George et al., 2010).

Nevertheless, a number of concerns were raised denoting some limitations of using MatSep as a model of ELS including: 1) there is a mismatch of environment and developmental period between humans and rodents since the postnatal life in mice aligns with the third trimester in humans; conversely, this mismatch provides a useful experimental model to perform interventions avoiding in utero manipulation, 2) emotional stress in humans is often self-perpetuated from an initial stressor, whereas in other animal species, stressors are often acute and non-self-perpetuated, thus allowing the researcher to evaluate the effect of stress in the absence of self-perpetuation and 3) there is remarkable consensus of effect across a variety of different MatSep protocols, but the development of a standardized protocol (e.g. time and length of separation) would help move the field forward.

Given that MatSep enhances the correlation between stress-induced cardiovascular outcomes, the use of an adequate protocol and species to study the molecular mechanisms by which ELS enhances adult cardiovascular disease risk can be proposed taking into account the nature of the phenotypic outcomes of interest.

\section{Mechanisms contributing to ELS-induced cardiovascular dysfunction}

\subsection{The central nervous system (CNS)}

The brain processes environmental input from emotional, sexual and physical abuse, neglect or illness differently at critical ages (Cirulli et al., 2009; Furukawa et al., 1999). It is wellaccepted that ELS has detrimental effects on adult health, especially when experienced through critical "windows of plasticity." During development, the timing of ELS can be harming if occurring when neural system differentiation and synapses are being formed and reinforced (Gershon and High, 2015). When children experience toxic stress, their cortisol levels remain elevated for prolonged periods of time. Both animal and human studies show that long-term elevations in cortisol levels can alter the function of a number of neural systems, suppress the immune response, and even change the architectural regions in the brain that are essential for processes such as learning and memory (Kumari et al., 2013; Pervanidou and Chrousos, 2011).

One mediator of neural function and plasticity is the brain derived neurotrophic factor (BDNF). It has been hypothesized that BDNF is a candidate molecule through which early life experiences persistently modify brain structure and function (Branchi et al., 2004). BDNF is active within the hippocampus, cortex, and basal forebrain and is important for cognitive function, energy homeostasis, long term memory and neurogenesis (Marosi and Mattson, 2014). While MatSep decreased BDNF decreased in hippocampus and striatum, it increased in ventral tegmental area. Unlike, cAMP response element binding protein (CREB) and fosB were unchanged in all brain regions from animals exposed to MatSep.

Recent Imaging studies on adults with a history of childhood stress revealed a significant impact in the frontal cortex, corpus callosum, amygdala, locus coeruleus, hippocampus, 
HPA axis and cerebellum (Brietzke et al., 2012; Hanson et al., 2015; Reynolds, 2013). As such, adults with a history of childhood adversity also have reduced hippocampus and prefrontal cortex volumes (Danese et al., 2009; McEwen et al., 2015).

It is important to discuss that in some condition, ELS during early stages of life exerts profound effects to impart resilience to later psycho-physiological dysfunction. A review of Dr. Meaney's work (Roth and David Sweatt, 2011) has described the molecular changes in the brain following high-quality maternal care that provided resilience to stress later in life. These adaptations were attributable to increased hippocampal glucocorticoid receptor (GR) expression, increased expression of transcription factor NGFI-A decreased hypothalamic corticotropin releasing factor (CRF) expression leading to enhanced glucocorticoid feedback sensitivity. This data further enforces that the quality of social support is the key event to determine exposure to or protection to secondary behavioral stressors (Ozbay et al., 2008; Smith and Carlson, 1997).

C57BL/6 inbred mice have been noted for resiliency to early environmental stressors (Anisman, 2001; Shanks et al., 1990). Selection for low or high care C57BL/6 mothers also has a minimal impact on offspring behavior and stress response (Pedersen et al., 2011). These studies suggest that alternative more severe models of ELS, beyond three hours, combined with early weaning are necessary to induce the ELS-like phenotype in mice (George et al., 2010; Ho et al., 2016).

\subsection{The Hypothalamic-Pituitary-Adrenal (HPA) Axis}

An important role of the hypothalamic-pituitary-adrenal (HPA) axis response is regulation of many biological systems in the body to allow an individual to adapt to its environment and promote survival (Munck et al., 1984). Glucocorticoid secretion improves cardiovascular tone, suppresses immune function, and mobilizes energy stores to enable the individual to cope with its environment including stressors. However, prolonged exposure to elevated glucorticoids has deleterious effects to many organ systems within the body including the central nervous system, immune system, and regulation of blood pressure (McCormick and Mathews, 2007; Woolley et al., 1990).

Through the actions of glucocorticoid hormone signaling in the brain, the HPA axis is involved in programming responses to future challenges, thereby influencing how an individual will respond to stressors in adulthood. Glucocorticoid secretion, which occurs with levels peaking in the morning and declining throughout the day in a diurnal pattern, are involved in the suppression of their own release through fast (seconds), delayed (minutes to hours), and slow (hours to days) negative feedback systems that inhibit the release of adrenocorticotrophin hormone (ACTH) (Dallman et al., 1987; Keller-Wood and Dallman, 1984). The hippocampal subiculum transynaptically inhibits the HPA axis by way of the bed nucleus. Experimentally, it was shown that (1) HPA-inhibitory influences of medial prefrontal cortex (mPFC) and hippocampal formation (HF), are additive and (2) anterior bed nucleus of the stria terminali (aBST) plays a more substantial inhibitory role over stressinduced HPA responses than ventral subiculum (Cullinan et al., 1993; Radley and Sawchenko, 2011). The hippocampus itself can become more damaged with increased exposure to stress (Brown et al., 1999), thus perpetuating this loss in feedback inhibition to 
the HPA axis. Electrical stimulation of the hippocampus has been shown to have an inhibitory effect on the HPA axis by reducing glucocorticoid levels (Herman et al., 2003). Lesion studies indicate that a damaged hippocampus prolongs HPA axis responses to acute stress (Herman et al., 1998) most likely through a genomic mechanism.

Hyporesponsive period in rodents-Early postnatal life is a sensitive period and there is a distinct pattern of HPA axis activity during early development that was first described in rodents. HPA axis activity maintains stable with low circulating glucocorticoids levels during the stress hyporesponsive period (SHRP) which corresponds to postnatal days 1-10 in mice and postnatal days 3-14 in rats (Sapolsky and Meaney, 1986; Schmidt et al., 2005; Stanton et al., 1988).

Prolonged maternal separation implemented during the SHRP causes neonates to display elevated basal and stress-induced levels of glucocorticoids, thus making the HPA axis hyperresponsive to future stressors. Chronic stress exposure during this period can have a longlasting impact on the HPA axis (Gunnar and Quevedo, 2007). Long-lasting alterations in the HPA axis induced by ELS in rodents have been linked to epigenetic modifications in regulatory regions of stress-related genes as described above. Specifically, impairment of mother-infant interactions during the postnatal period has been shown to upregulate hippocampal glucocorticoids receptor (GR) and to increase hypothalamic corticotropinreleasing factor (CRF), corticosterone, and ACTH levels (Korosi et al., 2010; Lehmann et al., 2000; Lippmann et al., 2007; Nishi et al., 2013)

Corticosterone levels and ACTH suppression-A key physiological response to stress involves the increased secretion of glucocorticoids. A major role of glucocorticoids is to regulate glucose mobilization during stressful periods as part of the adaptive response to stress. However, the adaptive responses to stress through glucocorticoids can become harmful when its threshold is exceeded. Excessive glucocorticoids lead to hyperlipidemia, hypertension and vasoconstriction, thus increasing the risk for cardiovascular events including myocardial infarction, stroke, and heart failure. MatSep has been shown to increase plasma corticosterone release and elevate Neuronal Growth Factor levels in the hippocampus, which can affect the development and maturation of specific organs that regulate blood pressure control including the heart, vasculature, kidney, and brain (Igosheva et al., 2004), suggesting that ELS presents the capability to exert programming effects.

To measure HPA activity, human populations often undergo a dexamethasone suppression test followed by a low dose ACTH stimulation test to examine pituitary and adrenal gland function by measuring urinary levels of cortisol. ELS is associated with persistent changes in HPA axis function, with ELS-exposed adults often exhibiting a flattened cortisol circadian rhythm and both hypo- and hyper-responsiveness to future stressors (Miller et al., 2013). A recent study examining the relationship between the HPA axis and cardiovascular risk factors in obese children revealed a positive association between systolic blood pressure and ACTH and cortisol levels (Prodam et al., 2013) thereby the risk for cardiovascular disease.

The mechanisms by which glucocorticoids and a dysfunctional HPA axis mediate the development of hypertension during postnatal life are still unclear. Numerous studies have 
demonstrated that acute or chronic exposure of the fetus to elevated maternal glucocorticoids during pregnancy programs the offspring for hypertension and cardiovascular disease (Moritz et al., 2003) (Ortiz et al., 2003, 2001). Additionally, glucocorticoids directly regulate blood pressure by increasing sodium and calcium intake within the vascular smooth muscle (Kornel et al., 1993) and by increasing vascular responsive to Ang II (Provencher et al., 1995) and noradrenaline (Bian et al., 1992). Nonetheless, few studies have addressed the long-term consequences of the exposure to elevated corticosterone levels during postnatal life using animal models. The glucocorticoid-induced changes in both central and peripheral sites of cardiovascular control may be reflected in enhanced cardiovascular responses to acute stress seen in MatSep mice (Pote et al., 2013) and rats (Loria et al., 2010b). Meaney's group has demonstrated that offspring exposed to less maternal care display elevated glucocorticoid responses to stress (Weaver et al., 2004). On the other, it has been shown that foster litters during maternal separation can prevent the sensitization of the HPA axis (Huot et al., 2004). These findings support the implication of the HPA-programmed sensitivity on the correlation between ELS and heightened response to stressors.

\subsection{The sympathetic nervous system (SNS)}

Sympathetic activation is one of the fastest systems in response to stressors (Farah et al., 2004; Lee et al., 2004; Randall et al., 1994). Acute stressors induce neuro-humoral and vascular responses that lead to greater blood pressure reactivity to stress or to delayed poststress blood pressure recovery (Chida and Steptoe, 2010; Gerin and Pickering, 1995). It has been shown that alteration in a single acute stress response event can predict future cardiovascular disease risk (Chen et al., 2007), such as stroke (Jern et al., 1989) and hypertension (Kohan and Padilla, 1994). Acute stress can trigger autonomic and neuroendocrine-mediated changes in cardiac contractility and peripheral vascular resistance (Reich et al., 1981) and involves vasoactive mediators such as plasma endothelin (ET-1) (Fujii et al., 2005; Kaehler et al., 2002), angiotensin II (Mayorov, 2011) and corticosterone (Taniyama and Griendling, 2003; Treiber et al., 2000).

While a large body of literature addresses the mechanisms by which SNS mediates the stress response, it is less frequent to find studies in animal models that have investigated the mechanisms underlying autonomic activation in response to emotional stress during postnatal life. The priming of the neuroendocrine responses to stress may have its origin in the brain as discussed above. In particular, we now know that early life abuse and neglect have adverse effects upon the developing brain and body that can result in poor self-control and emotional regulation, impaired cognitive development, and increased risk of cardiovascular, metabolic and immune system diseases (Boersma et al., 2014; Danese et al., 2009).

The neonatal rodent lacks the ability to produce sympathetic responses to hypoglycemia until the growth of the adrenal nerve supply has occurred. A surge in activity of postganglionic neurons occurs during the third postnatal week, which is associated with a profound elevation in the overall sympathetic hyperactivity and development of the baroreceptor regulation of sympathetic tone (Bartolome et al., 1980). However, it is possible that exposure to stressors early in this developmental queue accelerates a number of events, 
exacerbating the sensitivity of blood pressure regulatory mechanism such as the baroreflex function.

Four structurally related proteins including NGF brain-derived neurotrophic factor (BDNF), neurotrophin-3 (NT3), NT4/5, and NT6 have been considered as the key mediators of the ELS-induced developmental changes in the autonomic responses (McEwen et al., 2015; Murgatroyd et al., 2009; Weder et al., 2014). Nonetheless, the consequences of emotional stress during the specific window of plasticity on the reset of the sensitivity of the autonomic system have an amplificatory effect at the end-organ level, which will be further highlighted in the sections below.

Heart-Myocardium growth during the early postnatal period must respond not only to the increasing demands of the rapidly growing animal but also to the relatively sudden changes in the patterns of blood flow and circulatory resistance occurring shortly after birth. Cardiac tissue, specifically cardiomyocytes, undergoes structural and functional physiological changes that may be altered by exposure to behavioral stress (Anversa et al., 1980). The effect of MatSep on heart function has been reported in different animal models. Using borderline hypertensive rats (BHR), the first generation offspring of spontaneously hypertensive and Wistar-Kyoto rats, it was shown that MatSep alters the cardiovascular stress response induced by $30 \mathrm{~min}$ of restraint stress (Sanders and Anticevic, 2007). Despite a similar mean arterial pressure response, rats exposed to MatSep showed exaggerated heart rate response compared to control counterparts. MatSep also increased the stress-induced Fos positive cells in the central nucleus of the amygdala $(\mathrm{CeA})$, paraventricular nucleus of the hypothalamus (PVN), and the bed nucleus of the stria terminalis (BNST) (Sanders and Anticevic, 2007). These nuclei play an important role in integrating the physiological and behavioral response to stress. Thus, MatSep enhances the neuronal activation leading to an overactive autonomic system in response to stressful environmental cues.

Studies using Wistar rats reported that MatSep did not have a significant effect on the intermittent restraint stress (IRS)-induced acute modifications of cardiac sympathovagal balance (Trombini et al., 2012). Heart rate variability analysis has shown similar values as reported in non-MatSep rats. MatSep did not affect the autonomic blockade with scopolamine and atenolol, which suggests a normal cardiac pacemaker intrinsic activity. However, MatSep had a significant effect in cardiac parasympathetic drive following IRS (Trombini et al., 2012).

Taken together, these functional changes in the autonomic function of the heart have an effect on the cardiac structure involving cardiomyocyte hypertrophy, increased density of vascular structures, and myocardial fibrosis. Although these are considered mild functional and structural cardiac alterations, these changes confer increased susceptibility to the development of an exaggerated response to secondary stressors.

Vasculature-ET-1 is a 21-amino acid peptide characterized and purified from cultured endothelial cells (54). The actions of ET-1 are the result of activation of two receptor subtypes, ETA (located on vascular smooth muscle and mediates vasoconstriction) and ETB (predominantly expressed on the vascular endothelium) (Barton et al., 1998; D'Angelo et al., 
2005). Interestingly, both receptor subtypes are localized on sympathetic nerves (Milner et al., 2000). Studies have demonstrated a link between the ET-1 pathway and stress-induced raise in blood pressure in humans and rodents (D'Angelo et al., 2005; Kaehler et al., 2002; Spieker et al., 2002; Treiber et al., 2000). One potential link between ET-1 pathway and stress is given by the fact that exposure of vessels or cultured vascular smooth muscle cells from rat or rabbit to dexamethasone or cortisol resulted in concentration-dependent stimulation of endothelin release (Gómez-Guzmán et al., 2012; Intengan et al., 1998). Rats exposed to MatSep display acute stress-mediated ET release, indicating that alterations in the expression or function of the ET pathway may be implicated in the short- and/or longterm control of stress-induced responses. Specifically, MatSep exaggerates the acute blood pressure response to acute behavioral stress, which involves ET-1. In this regard, D'Angelo et al. (D'Angelo et al., 2005) suggested that there is a crosstalk between the ET-1 Type A (ETA) receptors and catecholamines in the terminal nerves, enhancing vasoconstriction. For instance, acute behavioral stress showed that the lack of ET-B receptor subtype in nonneuronal tissue, such as the vasculature, blunted the MatSep induced enhanced pressor response to stress that was observed in wild type MatSep rats (Loria et al., 2010a).

Furthermore, in normotensive rats, endogenous ETA receptor activation attenuates the air jet stress-mediated pressor response (D'Angelo et al., 2005). This data suggests a cross-talk between the ETA receptor and the adrenergic pathway (Mangiafico et al., 2002). However, MatSep reduced both ETA and ETB receptors expression in the vasculature. Thus, reduced ET receptor expression, particularly ETA might lead to exaggerated activation of the adrenergic-mediated responses in MatSep rats.

Kidneys-The role of the SNS in the development of hypertension has been described in several experimental models such as spontaneously hypertensive rats (SHR) and Dahl saltsensitive (DS) rats (D’Angelo et al., 2005; Mattson et al., 2004; Zicha et al., 2012). Additionally, kidneys play a critical role in the regulation of fluid homeostasis and chronic blood pressure control (Dahl and Heine, 1975; Navar, 1997). Renal denervation (DnX) is one of the most studied therapies for resistant hypertension (Esler et al., 2010; Osborn et al., 2005). In experimental models, Dr. Alexander's group showed that the exacerbated renal nerve activation plays a causal role in the early onset of hypertension in a model of intrauterine growth restriction (IUGR) (Alexander et al., 2005; Ojeda et al., 2007). Furthermore, Samuelsson et al show that sympathetic activation leads to hypertension in offspring from obese dams and is most likely derived from early exposure to energy-dense nutrients (Kirk et al., 2009; Samuelsson et al., 2013).

It has been reported that MatSep lowers the renal excretory capacity, or glomerular filtration rate (GFR) (Loria et al, 2013a). One of the mechanisms suggested involves an increased sympathetic outflow to the kidneys, since renal denervation normalized GFR in MatSep rats. Taken together, there is substantial evidence in the literature to support a profound effect of MatSep in the autonomic function. Thus, leading to exacerbated acute and chronic reactions to a wide range of environmental stressors, particularly the ones triggering blood pressure responsiveness. There is no proof of a direct sympathetic nerve activation involving baseline changes in HR and increased blood pressure due to exacerbated renal sodium retention. 
Overall, MatSep seems to impair the blood pressure regulation required to face the adaptive response to stimuli when a secondary stressor challenges the cardiovascular system.

\section{Perspectives for the study of ELS-induced cardiovascular dysfunction}

\subsection{The Renin-angiotensin-aldosterone system (RAAS)}

Many investigations have shown that alterations in normal vasculature development are associated with changes in renal structure/function with a subsequent impact on blood pressure levels (Gomez and Norwood, 1995; Sequeira Lopez and Gomez, 2004). However, there is a gap in knowledge regarding the impact of behavioral stress early in life and the mechanisms underlying the programming of the adult vascular phenotype.

The RAAS plays an important role in the vasculogenesis and angiogenesis processes (Gomez and Norwood, 1995; Sequeira Lopez and Gomez, 2004; Shi and Clegg, 2009; Tufro et al., 1999). The literature has not directly addressed the effect of stress in modulating these mechanisms; however, several studies have shown that models with increased GC levels during perinatal life are frequently associated with increases in Ang II sensitivity later in life. For instance, maternal GC exposure in sheep (Moritz et al., 2003) and low protein exposure in rats (McMullen and Langley-Evans, 2005; Woods et al., 2004) have been shown to induce marked changes in the renal renin-angiotensin system (RAAS) in the fetus and the offspring, suggesting that this system is of importance in many species and models of fetal programming.

In addition to the effects in the vasculature, the RAAS has been described as a required factor for a normal renal structural and functional development (Guron and Friberg, 2000; Lasaitiene et al., 2003; Saez et al., 2007). It is well-known that AT1 receptor blockade impairs the nephron endowment and induces structural damage leading to the development of hypertension later in life. However, the effects of chronic stress during the late nephrogenic period have not been investigated. In Wistar Kyoto rats, MatSep lowers GFR in baseline conditions, although the histopathology of these animals is normal (Loria et al., 2013a, 2013b). However, chronic AngII administration exaggerates hypertension. In these conditions, the kidney but not the conductance vessels from the MatSep animals show vascular damage, suggesting that exposure to AngII most likely induces a renal-dependent hypertension. Thus, reduced renal filtration capacity is a potential mechanism by which MatSep impairs chronic blood pressure control. Since the vascular development is an event highly associated with the circulating and local levels of AngII and the expression of AT1 and AT2 receptors as well, further investigations to address the connections between stress and cardiovascular sensitivity to AngII are required.

\subsection{The Inflammatory system}

Humans exposed to ELS display a heightened inflammatory status that parallels what is observed in rodent models of ELS (Clarke et al., 2009; Danese et al., 2007; Slopen et al., 2012). Adults who reported experiences of childhood maltreatment demonstrated an attenuated HPA axis sensitivity in response to a psychosocial stress test (Heim et al., 2000). Since glucocorticoids exert an inhibitory influence on inflammation, it is possible that 
maltreated children display increased levels of inflammation in adulthood through this mechanism. Furthermore, adults reporting ELS or ACEs have been shown to be at an increased risk of disease associated with an inflammatory origin (Dong et al., 2004; Felitti et al., 1998). The persistent activation of inflammatory pathways is proposed as one of the mechanisms by which ELSalter long-term cardiovascular status since inflammation is a central part of the stress response (Glaser and Kiecolt-Glaser, 2013). In the context of the "fight or flight" reaction, acute psychosocial stress can induce activation of the transcription nuclear factor $\mathrm{kB}(\mathrm{NFkB})$ and secretion of proinflammatory cytokines (Bierhaus et al., 2003; Maes et al., 1998). As such, through the production of proinflammatory cytokines, immune activation progressively stimulates the secretion of glucocorticoids (Flier, 1995). These events have been shown to induce hypertension and promote cardiovascular disease. Thus, ELS may disrupt the potentially adaptive response to stress. Animal models suggest that maternal care influences the development of the stress response (Caldji et al., 1998; Weaver et al., 2004) and may alter the long-term susceptibility to inflammation (Bailey and Coe, 1999).

The Dunedin Multidisciplinary Health and Development Study, one of the few prospective studies in a birth cohort followed to age 32 years revealed that maltreated children display a significant and graded increase in the risk for clinically relevant C-reactive protein levels 20 years later (Danese et al., 2007). This investigation also shows that more than $10 \%$ of cases of low-grade inflammation in the population may be secondary to adverse childhood experiences. The association between childhood adversity and adult inflammation also generalizes to fibrinogen and white blood cell count (Raposa et al., 2014).

Likewise, adult animals subjected to chronic stress show an inflammatory response in the hippocampus; which has been related to cognitive dysfunction and psychopathology. MatSep activates microglial cells and decreases astrocyte density in the hippocampus. A differential cytokine expression was observed in the hippocampus and the hypothalamus after MatSep and in response to an acute stressor. Also, MatSep induced an independent response of peripheral cytokines, where peripheral concentrations of IL-1 $\beta$ were decreased and IL-6 concentrations were increased after a single acute stress event in MatSep pups at postnatal day 15 (Roque et al., 2015). Taken together, this studies reveals that ELS is associated with persistent elevations in proinflammatory cytokines; however, future studies are needed to elucidate the molecular mechanisms.

\subsection{Epigenetics}

Developmental and behavioral neuroscience research continues to provide evidence that the epigenome remains sensitive to environmental influences. Epigenetics is the study of heritable, but modifiable, changes in gene expression, and permits an individual's biological systems to adapt to its environment by changing the methylation patterns (Berger et al., 2009). Epigenetic mechanisms mediate gene-environment interplay during the lifespan. Post-translational modifications of histones and DNA methylation have been intensely studied and the growing body of evidence indicates that changes in gene activity are a result of a variety of environmental factors including, toxins, stress, diet and behaviorally relevant stimuli (Gershon and High, 2015a; Vaiserman, 2014b; Yang et al., 2013). 
Among the mechanisms that change the normal function of genes and/or neurons, changes in DNA methylation have been shown to play a critical role in the development of chronic disease in response to stress (Gershon and High, 2015; Murgatroyd and Spengler, 2011; Weder et al., 2014). Specifically, challenges during early neonatal life alter the gene promoter methylation and therefore directly or indirectly effect gene expression in a range of physiological processes (Gluckman et al., 2008). In rats, several models of fetal programming have extensively described these effects. Altered promoter methylation and gene expression have been shown in the hepatic GR and the peroxisome proliferatoractivated receptor (PPAR-a), influencing carbohydrate and lipid metabolism (Burdge et al., 2008; Lillycrop et al., 2005). Other epigenetic changes have been observed in p53 of the kidney (Pham et al., 2003) and the angiotensin II type $1 \mathrm{~b}$ receptor in the adrenal gland (Bogdarina et al., 2007) influencing renal apoptosis and pressor responses, respectively. These phenotypic effects may not manifest until later in life in response to inadequate nutritional factors such as a high fat diet (Gluckman et al., 2008).

Also, a significant attenuation of methylation at several $\mathrm{CpG}$ sites in the paraventricular nucleus (PVN) has been found even one year after exposure to MatSep in male mice (Kember et al., 2012). To test the hypothesis of correlation between rodent versus human ELS-induced epigenetic changes, a study of male suicide victims' hippocampi exhibited decreased levels of GR, which correlated with increased methylation in the $\mathrm{Nr} 3 \mathrm{c} 1$ promoter, the human GR (McGowan et al., 2009) (Murgatroyd and Spengler, 2011). Taken together, these data indicate that ELS modify the epigenetic landscape at multiple levels, including the modification of key regulators of the stress and cardiovascular responses.

\section{Summary}

Among the numerous environmental factors that affect the programming of the cardiovascular system, chronic behavioral stress during early life emerges as an independent risk factor. A multi-organic response in adaptation to this first exposure to stress early in life induces long lasting effects on the responsiveness to secondary stimuli, increasing the risk to develop chronic disease (Figure 1). Focusing on the psychological and cardiovascular comorbidity, a compelling number of mechanisms triggered by stress have been shown to have a major impact in the neuroendocrine plasticity associated with the regulation of cardiovascular function. This review also reveals that there is a need for further investigation in the ELS-induced mechanisms underlying future risk of premature morbidity and mortality. In the quest to understand the systems and mechanisms involved with organ and tissue plasticity, it is important to consider these pathways to develop a more personalized pharmacotherapy to alleviate the long-term effects of ELS, including ACEs.

Benefits of early intervention, efforts to curb child psycho-emotional and physical abuse, could reduce hypertension and heart disease in the adult population (Alastalo et al., 2013; Gluckman et al., 2008; Lehman et al., 2009; Parrish et al., 2013). Yet, sensitivity of the developing brain provides an opportunity for improving outcomes, and this is leading to efforts to improve consistency of supportive parental care. 


\section{Acknowledgments}

Funding sources

This study was supported by grants from the NIH National Heart, Lung, and Blood Institute (A. S. Loria: K99 HL111354).

\section{References}

Aguilera G, Rabadan-Diehl C. Vasopressinergic regulation of the hypothalamic-pituitary-adrenal axis: Implications for stress adaptation. Regul Pept. 2000; 96:23-29. DOI: 10.1016/ S0167-0115(00)00196-8 [PubMed: 11102648]

Alastalo H, Räikkönen K, Pesonen AK, Osmond C, Barker DJP, Heinonen K, Kajantie E, Eriksson JG. Early life stress and blood pressure levels in late adulthood. J Hum Hypertens. 2013; 27:90-4. DOI: 10.1038/jhh.2012.6 [PubMed: 22336905]

Alexander BT, Hendon AE, Ferril G, Dwyer TM. Renal denervation abolishes hypertension in lowbirth-weight offspring from pregnant rats with reduced uterine perfusion. Hypertension. 2005; 45:754-758. DOI: 10.1161/01.HYP.0000153319.20340.2a [PubMed: 15699462]

Anda RF, Dong M, Brown DW, Felitti VJ, Giles WH, Perry GS, Valerie EJ, Dube SR. The relationship of adverse childhood experiences to a history of premature death of family members. BMC Public Health. 2009; 9:106.doi: 10.1186/1471-2458-9-106 [PubMed: 19371414]

Anversa P, Olivetti G, Loud AV. Morphometric study of early postnatal development in the left and right ventricular myocardium of the rat. I Hypertrophy, hyperplasia, and binucleation of myocytes. Circ Res. 1980; 46:495-502. DOI: 10.1161/01.RES.46.4.495 [PubMed: 6444554]

Bailey MT, Coe CL. Maternal separation disrupts the integrity of the intestinal microflora in infant rhesus monkeys. Dev Psychobiol. 1999; 35:146-155. pii. [PubMed: 10461128]

Bartolome J, Mills E, Lau C, Slotkin TA. Maturation of sympathetic neurotransmission in the rat heart. V Development of baroreceptor control of sympathetic tone. J Pharmacol Exp Ther. 1980; 215:596600. [PubMed: 6255133]

Barton M, d'Uscio LV, Shaw S, Meyer P, Moreau P, Lüscher TF. ET(A) receptor blockade prevents increased tissue endothelin-1, vascular hypertrophy, and endothelial dysfunction in salt-sensitive hypertension. Hypertension. 1998; 31:499-504. DOI: 10.1161/01.HYP.31.1.499 [PubMed: 9453352]

Berger SL, Kouzarides T, Shiekhattar R, Shilatifard A. An operational definition of epigenetics. Genes Dev. 2009; 23:781-783. DOI: 10.1101/gad.1787609 [PubMed: 19339683]

Beutel ME, Wiltink J, Kirschner Y, Sinning C, Espinola-Klein C, Wild PS, Münzel T, Blettner M, Zwiener I, Lackner K, Michal M. History of depression but not current depression is associated with signs of atherosclerosis: data from the Gutenberg Health Study. Psychol Med. 2014; 44:91925. DOI: 10.1017/S0033291713001542 [PubMed: 23822954]

Bian XP, Seidler FJ, Slotkin TA. Promotional role for glucocorticoids in the development of intracellular signalling: enhanced cardiac and renal adenylate cyclase reactivity to beta-adrenergic and non-adrenergic stimuli after low-dose fetal dexamethasone exposure. J Dev Physiol. 1992; 17:289-97. [PubMed: 1337750]

Bierhaus A, Wolf J, Andrassy M, Rohleder N, Humpert PM, Petrov D, Ferstl R, von Eynatten M, Wendt T, Rudofsky G, Joswig M, Morcos M, Schwaninger M, McEwen B, Kirschbaum C, Nawroth PP. A mechanism converting psychosocial stress into mononuclear cell activation. Proc Natl Acad Sci U S A. 2003; 100:1920-1925. DOI: 10.1073/pnas.0438019100 [PubMed: 12578963]

Boersma GJ, Bale TL, Casanello P, Lara HE, Lucion AB, Suchecki D, Tamashiro KL. Long-term impact of early life events on physiology and behaviour. J Neuroendocrinol. 2014; 26:587-602. DOI: 10.1111/jne.12153 [PubMed: 24690036]

Bogdarina I, Welham S, King PJ, Burns SP, Clark AJL. Epigenetic modification of the reninangiotensin system in the fetal programming of hypertension. Circ Res. 2007; 100:520-6. DOI: 10.1161/01.RES.0000258855.60637.58 [PubMed: 17255528] 
Branchi I, Francia N, Alleva E. Epigenetic control of neurobehavioural plasticity: the role of neurotrophins. Behav Pharmacol. 2004; 15:353-62. [PubMed: 15343058]

Brent DA, Silverstein M. Shedding light on the long shadow of childhood adversity. JAMA. 2013; 309:1777-8. DOI: 10.1001/jama.2013.4220 [PubMed: 23632718]

Brietzke E, Sant'anna MK, Jackowski A, Grassi-Oliveira R, Bucker J, Zugman A, Mansur RB, Bressan RA. Impact of Childhood Stress on Psychopathology. Rev Bras Psiquiatr. 2012; 34:480 488. DOI: 10.1016/j.rbp.2012.04.009 [PubMed: 23429820]

Brown ES, Rush AJ, McEwen BS. Hippocampal remodeling and damage by corticosteroids: implications for mood disorders. Neuropsychopharmacology. 1999; 21:474-84. DOI: 10.1016/ S0893-133X(99)00054-8 [PubMed: 10481830]

Burdge GC, Lillycrop KA, Jackson AA, Gluckman PD, Hanson MA. The nature of the growth pattern and of the metabolic response to fasting in the rat are dependent upon the dietary protein and folic acid intakes of their pregnant dams and post-weaning fat consumption. Br J Nutr. 2008; 99:540-9. DOI: 10.1017/S0007114507815819 [PubMed: 17761015]

Caldji C, Tannenbaum B, Sharma S, Francis D, Plotsky PM, Meaney MJ. Maternal care during infancy regulates the development of neural systems mediating the expression of fearfulness in the rat. Proc Natl Acad Sci U S A. 1998; 95:5335-5340. DOI: 10.1073/pnas.95.9.5335 [PubMed: 9560276]

Carroll JE, Gruenewald TL, Taylor SE, Janicki-Deverts D, Matthews KA, Seeman TE. Childhood abuse, parental warmth, and adult multisystem biological risk in the Coronary Artery Risk Development in Young Adults study. Proc Natl Acad Sci U S A. 2013; 110:17149-53. DOI: 10.1073/pnas. 1315458110 [PubMed: 24062432]

Chen Y, Pearlman A, Luo Z, Wilcox CS. Hydrogen peroxide mediates a transient vasorelaxation with tempol during oxidative stress. Am J Physiol Heart Circ Physiol. 2007; 293:H2085-92. DOI: 10.1152/ajpheart.00968.2006 [PubMed: 17644566]

Chida Y, Steptoe A. Greater cardiovascular responses to laboratory mental stress are associated with poor subsequent cardiovascular risk status: A meta-analysis of prospective evidence. Hypertension. 2010; 55:1026-1032. DOI: 10.1161/HYPERTENSIONAHA.109.146621 [PubMed: 20194301]

Cirulli F, Laviola G, Ricceri L. Risk factors for mental health: Translational models from behavioural neuroscience. Neurosci Biobehav Rev. 2009; 33:493-497. DOI: 10.1016/j.neubiorev.2009.01.006 [PubMed: 19415818]

Clarke G, O’Mahony SM, Hennessy AA, Ross P, Stanton C, Cryan JF, Dinan TG. Chain reactions: early-life stress alters the metabolic profile of plasma polyunsaturated fatty acids in adulthood. Behav Brain Res. 2009; 205:319-21. DOI: 10.1016/j.bbr.2009.07.008 [PubMed: 19616034]

Cullinan WE, Herman JP, Watson SJ. Ventral subicular interaction with the hypothalamic paraventricular nucleus: Evidence for a relay in the bed nucleus of the stria terminalis. J Comp Neurol. 1993; 332:1-20. DOI: 10.1002/cne.903320102 [PubMed: 7685778]

D’Angelo G, Pollock JS, Pollock DM. Endogenous endothelin attenuates the pressor response to acute environmental stress via the ETA receptor. Am J Physiol Hear Circ Physiol. 2005; 288:H1829-35. DOI: 10.1152/ajpheart.00844.2004

Dahl LK, Heine M. Primary role of renal homografts in setting chronic blood pressure levels in rats. Circ Res. 1975; 36:692-696. DOI: 10.1161/01.RES.36.6.692 [PubMed: 1093748]

Dallman MF, Akana SF, Cascio CS, Darlington DN, Jacobson L, Levin N. Regulation of ACTH secretion: variations on a theme of B. Recent Prog Horm Res. 1987; 43:113-73. [PubMed: 2819993]

Danese A, Moffitt TE, Harrington H, Milne BJ, Polanczyk G, Pariante CM, Poulton R, Caspi A. Adverse childhood experiences and adult risk factors for age-related disease: depression, inflammation, and clustering of metabolic risk markers. Arch Pediatr Adolesc Med. 2009; 163:1135-43. DOI: 10.1001/archpediatrics.2009.214 [PubMed: 19996051]

Danese A, Pariante CM, Caspi A, Taylor A, Poulton R. Childhood maltreatment predicts adult inflammation in a life-course study. Proc Natl Acad Sci U S A. 2007; 104:1319-24. DOI: 10.1073/ pnas.0610362104 [PubMed: 17229839]

Daskalakis NP, Bagot RC, Parker KJ, Vinkers CH, de Kloet ER. The three-hit concept of vulnerability and resilience: toward understanding adaptation to early-life adversity outcome. 
Psychoneuroendocrinology. 2013; 38:1858-73. DOI: 10.1016/j.psyneuen.2013.06.008 [PubMed: 23838101]

Davidson KW. Depression and coronary heart disease. ISRN Cardiol. 2012; 2012:743813.doi: 10.5402/2012/743813 [PubMed: 23227360]

Dong M, Giles WH, Felitti VJ, Dube SR, Williams JE, Chapman DP, Anda RF. Insights into causal pathways for ischemic heart disease: adverse childhood experiences study. Circulation. 2004; 110:1761-6. DOI: 10.1161/01.CIR.0000143074.54995.7F [PubMed: 15381652]

Esler MD, Krum H, Sobotka PA, Schlaich MP, Schmieder RE, Böhm M. Renal sympathetic denervation in patients with treatment-resistant hypertension (The Symplicity HTN-2 Trial): a randomised controlled trial. Lancet. 2010; 376:1903-9. DOI: 10.1016/S0140-6736(10)62039-9 [PubMed: 21093036]

Evans GW, Exner-Cortens D, Kim P, Bartholomew D. Childhood poverty and blood pressure reactivity to and recovery from an acute stressor in late adolescence: the mediating role of family conflict. Psychosom Med. 2013; 75:691-700. DOI: 10.1097/PSY.0b013e31829f9823 [PubMed: 23960158]

Fabricius K, Wörtwein G, Pakkenberg B. The impact of maternal separation on adult mouse behaviour and on the total neuron number in the mouse hippocampus. Brain Struct Funct. 2008; 212:403416. DOI: 10.1007/s00429-007-0169-6 [PubMed: 18200448]

Farah VMA, Joaquim LF, Bernatova I, Morris M. Acute and chronic stress influence blood pressure variability in mice. Physiol Behav. 2004; 83:135-142. DOI: 10.1016/j.physbeh.2004.08.004 [PubMed: 15501500]

Felitti VJ, Anda RF, Nordenberg D, Williamson DF, Spitz AM, Edwards V, Koss MP, Marks JS. Relationship of childhood abuse and household dysfunction to many of the leading causes of death in adults. The Adverse Childhood Experiences (ACE) Study. Am J Prev Med. 1998; 14:245-58. [PubMed: 9635069]

Filipović D, Gavrilović L, Dronjak S, Radojcić MB. Brain glucocorticoid receptor and heat shock protein 70 levels in rats exposed to acute, chronic or combined stress. Neuropsychobiology. 2005; 51:107-14. DOI: 10.1159/000084168 [PubMed: 15741752]

Flier J. The hypothalamic-pituitary-adrenal axis and immune-mediated inflammation. New Engl J .... 1995; 332:1351-1362. DOI: 10.1056/NEJM199505183322008

Freedman DS, Mei Z, Srinivasan SR, Berenson GS, Dietz WH. Cardiovascular risk factors and excess adiposity among overweight children and adolescents: the Bogalusa Heart Study. J Pediatr. 2007; 150:12-17. e2. DOI: 10.1016/j.jpeds.2006.08.042 [PubMed: 17188605]

Fujii T, Takaoka M, Ohkita M, Matsumura Y. Tempol protects against ischemic acute renal failure by inhibiting renal noradrenaline overflow and endothelin-1 overproduction. Biol Pharm Bull. 2005; 28:641-5. [PubMed: 15802802]

Furukawa, Ta, Ogura, a, Hirai, T., Fujihara, S., Kitamura, T., Takahashi, K. Early parental separation experiences among patients with bipolar disorder and major depression: a case-control study. $\mathbf{J}$ Affect Disord. 1999; 52:85-91. [PubMed: 10357021]

George ED, Bordner KA, Elwafi HM, Simen AA. Maternal separation with early weaning: a novel mouse model of early life neglect. BMC Neurosci. 2010; 11:123.doi: 10.1186/1471-2202-11-123 [PubMed: 20920223]

Gerin W, Pickering TG. Association between delayed recovery of blood pressure after acute mental stress and parental history of hypertension. J Hypertens. 1995; 13:603-610. DOI: 10.1097/00004872-199506000-00005 [PubMed: 7594416]

Gershon NB, High PC. Epigenetics and child abuse: Modern-day Darwinism - the miraculous ability of the human genome to adapt, and then adapt again. Am J Med Genet C Semin Med Genet. 2015; doi: 10.1002/ajmg.c.31467

Ginty AT, Williams SE, Jones A, Roseboom TJ, Phillips AC, Painter RC, Carroll D, de Rooij SR. Diminished heart rate reactivity to acute psychological stress is associated with enhanced carotid intima-media thickness through adverse health behaviors. Psychophysiology. 2016; 53:769-75. DOI: 10.1111/psyp.12640 [PubMed: 27005834]

Glaser R, Kiecolt-Glaser JK. Stress-Induced Immune Dysfunction: Implications for Health. Nat Rev Immunol. 2013; 5:1241-1252. DOI: 10.3390/nu5041241 
Glassman AH. Depression and cardiovascular comorbidity. Dialogues Clin Neurosci. 2007; 9:9-17. [PubMed: 17506222]

Gluckman PD, Hanson MA, Cooper C, Thornburg KL. Effect of in utero and early-life conditions on adult health and disease. N Engl J Med. 2008; 359:61-73. DOI: 10.1056/NEJMra0708473 [PubMed: 18596274]

Gomez RA, Norwood VF. Developmental consequences of the renin-angiotensin system. Am J Kidney Dis. 1995; 26:409-431. DOI: 10.1016/0272-6386(95)90487-5 [PubMed: 7645550]

Gómez-Guzmán M, Jiménez R, Sánchez M, Zarzuelo MJ, Galindo P, Quintela AM, López-Sepúlveda R, Romero M, Tamargo J, Vargas F, Pérez-Vizcaíno F, Duarte J. Epicatechin lowers blood pressure, restores endothelial function, and decreases oxidative stress and endothelin-1 and NADPH oxidase activity in DOCA-salt hypertension. Free Radic Biol Med. 2012; 52:70-79. DOI: 10.1016/j.freeradbiomed.2011.09.015 [PubMed: 22001745]

Gunnar M, Quevedo K. The neurobiology of stress and development. Annu Rev Psychol. 2007; 58:145-73. DOI: 10.1146/annurev.psych.58.110405.085605 [PubMed: 16903808]

Guron G, Friberg P. An intact renin-angiotensin system is a prerequisite for normal renal development. J Hypertens. 2000; 18:123-37. [PubMed: 10694179]

Halaris A. Comorbidity between depression and cardiovascular disease. Int Angiol. 2009; 28:92-99. [PubMed: 19367238]

Hanson JL, Albert WD, Iselin A-MR, Carré JM, Dodge KA, Hariri AR. Cumulative Stress In Childhood is Associated with Blunted Reward-Related Brain Activity In Adulthood. Soc Cogn Affect Neurosci. 2015; :nsv124.doi: 10.1093/scan/nsv124

Harris A, Seckl J. Glucocorticoids, prenatal stress and the programming of disease. Horm Behav. 2011; 59:279-89. DOI: 10.1016/j.yhbeh.2010.06.007 [PubMed: 20591431]

Heim C, Binder EB. Current research trends in early life stress and depression: review of human studies on sensitive periods, gene-environment interactions, and epigenetics. Exp Neurol. 2012; 233:102-11. DOI: 10.1016/j.expneurol.2011.10.032 [PubMed: 22101006]

Heim CM, Newport DJ, Heit S, Graham YP, Wilcox M, Bonsall R, Miller AH, Nemeroff CB. Pituitary-adrenal and autonomic responses to stress in women after sexual and physical abuse in childhood. JAMA. 2000; 284:592-7. [PubMed: 10918705]

Herman JP, Dolgas CM, Carlson SL. Ventral subiculum regulates hypothalamo-pituitaryadrenocortical and behavioural responses to cognitive stressors. Neuroscience. 1998; 86:449-59. [PubMed: 9881860]

Herman JP, Figueiredo H, Mueller NK, Ulrich-Lai Y, Ostrander MM, Choi DC, Cullinan WE. Central mechanisms of stress integration: hierarchical circuitry controlling hypothalamo-pituitaryadrenocortical responsiveness. Front Neuroendocrinol. 2003; 24:151-80. [PubMed: 14596810]

Ho DH, Burch ML, Musall B, Musall JB, Hyndman KA, Pollock JS. Early life stress in male mice induces superoxide production and endothelial dysfunction in adulthood. Am J Physiol Heart Circ Physiol. 2016; 310:H1267-74. DOI: 10.1152/ajpheart.00016.2016 [PubMed: 26921433]

Huffman JC, Celano CM, Beach SR, Motiwala SR, Januzzi JL. Depression and cardiac disease: epidemiology, mechanisms, and diagnosis. Cardiovasc Psychiatry Neurol. 2013; 2013:695925.doi: 10.1155/2013/695925 [PubMed: 23653854]

Huot RL, Gonzalez ME, Ladd CO, Thrivikraman KV, Plotsky PM. Foster litters prevent hypothalamicpituitary-adrenal axis sensitization mediated by neonatal maternal separation. Psychoneuroendocrinology. 2004; 29:279-289. DOI: 10.1016/S0306-4530(03)00028-3 [PubMed: 14604606]

Igosheva N, Klimova O, Anishchenko T, Glover V. Prenatal stress alters cardiovascular responses in adult rats. J Physiol. 2004; 557:273-85. DOI: 10.1113/jphysiol.2003.056911 [PubMed: 15034122]

Intengan HD, He G, Schiffrin EL. Effect of vasopressin antagonism on structure and mechanics of small arteries and vascular expression of endothelin-1 in deoxycorticosterone acetate salt hypertensive rats. Hypertension. 1998; 32:770-7. [PubMed: 9774378]

Jern C, Eriksson E, Tengborn L, Risberg B, Wadenvik H, Jern S. Changes of plasma coagulation and fibrinolysis in response to mental stress. Thromb Haemost. 1989; 62:767-71. [PubMed: 2814924]

Joung KE, Park KH, Zaichenko L, Sahin-Efe A, Thakkar B, Brinkoetter M, Usher N, Warner D, Davis $\mathrm{CR}$, Crowell JA, Mantzoros CS. Early life adversity is associated with elevated levels of 
circulating leptin, irisin, and decreased levels of adiponectin in midlife adults. J Clin Endocrinol Metab. 2014; 99:E1055-60. DOI: 10.1210/jc.2013-3669 [PubMed: 24650014]

Kaehler J, Sill B, Koester R, Mittmann C, Orzechowski H-D, Muenzel T, Meinertz T. Endothelin-1 mRNA and protein in vascular wall cells is increased by reactive oxygen species. Clin Sci (Lond). 2002; 103(Suppl):176S-178S. DOI: 10.1042/CS103S176S [PubMed: 12193080]

Katz DA, Sprang G, Cooke C. The cost of chronic stress in childhood: understanding and applying the concept of allostatic load. Psychodyn Psychiatry. 2012; 40:469-80. DOI: 10.1521/pdps. 2012.40.3.469 [PubMed: 23002705]

Keller-Wood ME, Dallman MF. Corticosteroid inhibition of ACTH secretion. Endocr Rev. 1984; 5:124. DOI: 10.1210/edrv-5-1-1 [PubMed: 6323158]

Kember RL, Dempster EL, Lee THa, Schalkwyk LC, Mill J, Fernandes C. Maternal separation is associated with strain-specific responses to stress and epigenetic alterations to $\mathrm{Nr} 3 \mathrm{c} 1$, Avp, and Nr4a1 in mouse. Brain Behav. 2012; 2:455-467. DOI: 10.1002/brb3.69 [PubMed: 22950049]

Kirk SL, Samuelsson AM, Argenton M, Dhonye H, Kalamatianos T, Poston L, Taylor PD, Coen CW. Maternal obesity induced by diet in rats permanently influences central processes regulating food intake in offspring. PLoS One. 2009; :4.doi: 10.1371/journal.pone.0005870

Kohan DE, Padilla E. Endothelin-1 production by rat inner medullary collecting duct: effect of nitric oxide, cGMP, and immune cytokines. Am J Physiol. 1994; 266:F291-7. [PubMed: 8141330]

Kornel L, Manisundaram B, Nelson WA. Glucocorticoids regulate Na+ transport in vascular smooth muscle through the glucocorticoid receptor-mediated mechanism. Am J Hypertens. 1993; 6:73644. [PubMed: 8110426]

Korosi A, Shanabrough M, McClelland S, Liu ZW, Borok E, Gao XB, Horvath TL, Baram TZ. Earlylife experience reduces excitation to stress-responsive hypothalamic neurons and reprograms the expression of corticotropin-releasing hormone. J Neurosci. 2010; 30:703-13. DOI: 10.1523/ JNEUROSCI.4214-09.2010 [PubMed: 20071535]

Kumari M, Head J, Bartley M, Stansfeld S, Kivimaki M. Maternal separation in childhood and diurnal cortisol patterns in mid-life: findings from the Whitehall II study. Psychol Med. 2013; 43:633-43. DOI: 10.1017/S0033291712001353 [PubMed: 22785027]

Lasaitiene D, Chen Y, Guron G, Marcussen N, Tarkowski A, Telemo E, Friberg P. Perturbed medullary tubulogenesis in neonatal rat exposed to renin-angiotensin system inhibition. Nephrol Dial Transplant. 2003; 18:2534-2541. DOI: 10.1093/ndt/gfg447 [PubMed: 14605275]

Lee DL, Webb RC, Brands MW. Sympathetic and angiotensin-dependent hypertension during cageswitch stress in mice. Am J Physiol Regul Integr Comp Physiol. 2004; 287:R1394-R1398. DOI: 10.1152/ajpregu.00306.2004 [PubMed: 15308486]

Lehman BJ, Taylor SE, Kiefe CI, Seeman TE. Relationship of early life stress and psychological functioning to blood pressure in the CARDIA study. Health Psychol. 2009; 28:338-46. DOI: 10.1037/a0013785 [PubMed: 19450040]

Lehmann J, Stöhr T, Feldon J. Long-term effects of prenatal stress experiences and postnatal maternal separation on emotionality and attentional processes. Behav Brain Res. 2000; 107:133-44. [PubMed: 10628737]

Lillycrop KA, Phillips ES, Jackson AA, Hanson MA, Burdge GC. Dietary protein restriction of pregnant rats induces and folic acid supplementation prevents epigenetic modification of hepatic gene expression in the offspring. J Nutr. 2005; 135:1382-6. [PubMed: 15930441]

Lippmann M, Bress A, Nemeroff CB, Plotsky PM, Monteggia LM. Long-term behavioural and molecular alterations associated with maternal separation in rats. Eur J Neurosci. 2007; 25:3091-8. DOI: 10.1111/j.1460-9568.2007.05522.x [PubMed: 17561822]

Loria AS, Brands MW, Pollock DM, Pollock JS. Early life stress sensitizes the renal and systemic sympathetic system in rats. Am J Physiol Renal Physiol. 2013a; 305:F390-5. DOI: 10.1152/ ajprenal.00008.2013 [PubMed: 23678041]

Loria AS, D’Angelo G, Pollock DM, Pollock JS. Early life stress downregulates endothelin receptor expression and enhances acute stress-mediated blood pressure responses in adult rats. Am J Physiol Regul Integr Comp Physiol. 2010a; 299:R185-91. DOI: 10.1152/ajpregu.00333.2009 [PubMed: 20410476] 
Loria AS, Ho DH, Pollock JS. A mechanistic look at the effects of adversity early in life on cardiovascular disease risk during adulthood. Acta Physiol (Oxf). 2013; doi: 10.1111/apha.12189

Loria AS, Pollock DM, Pollock JS. Early life stress sensitizes rats to angiotensin II-induced hypertension and vascular inflammation in adult life. Hypertension. 2010b; 55:494-9. DOI: 10.1161/HYPERTENSIONAHA.109.145391 [PubMed: 20026758]

Loria AS, Yamamoto T, Pollock DM, Pollock JS. Early life stress induces renal dysfunction in adult male rats but not female rats. Am J Physiol Regul Integr Comp Physiol. 2013b; 304:R121-9. DOI: 10.1152/ajpregu.00364.2012 [PubMed: 23174859]

Low CA, Salomon K, Matthews KA. Chronic life stress, cardiovascular reactivity, and subclinical cardiovascular disease in adolescents. Psychosom Med. 2009; 71:927-931. DOI: 10.1097/PSY. 0b013e3181ba18ed [PubMed: 19737856]

Luecken LJ. Childhood attachment and loss experiences affect adult cardiovascular and cortisol function. Psychosom Med. 1998; 60:765-772. [PubMed: 9847038]

Maes M, Song C, Lin a, De Jongh R, Van Gastel a, Kenis G, Bosmans E, De Meester I, Benoy I, Neels H, Demedts P, Janca a, Scharpé S, Smith RS. The effects of psychological stress on humans: increased production of pro-inflammatory cytokines and a Th1-like response in stress-induced anxiety. Cytokine. 1998; 10:313-318. DOI: 10.1006/cyto.1997.0290 [PubMed: 9617578]

Mangiafico RA, Malatino LS, Attinà T, Messina R, Fiore CE. Exaggerated endothelin release in response to acute mental stress in patients with intermittent claudication. Angiology. n.d; 53:38390. [PubMed: 12143942]

Marin MF, Lord C, Andrews J, Juster RP, Sindi S, Arsenault-Lapierre G, Fiocco AJ, Lupien SJ. Chronic stress, cognitive functioning and mental health. Neurobiol Learn Mem. 2011; 96:583-595. DOI: 10.1016/j.nlm.2011.02.016 [PubMed: 21376129]

Marosi K, Mattson MP. BDNF mediates adaptive brain and body responses to energetic challenges. Trends Endocrinol Metab. 2014; 25:89-98. DOI: 10.1016/j.tem.2013.10.006 [PubMed: 24361004]

Mascitelli L, Pezzetta F, Sullivan JL. Why women live longer than men: sex differences in longevity. Gend Med. 2006; 3:341. author reply 342. [PubMed: 17582374]

Matthews KA, Woodall KL, Stoney CM. Changes in and stability of cardiovascular responses to behavioral stress: results from a four-year longitudinal study of children. Child Dev. 1990; 61:1134-44. [PubMed: 2209183]

Mattson DL, Kunert MP, Kaldunski ML, Greene AS, Roman RJ, Jacob HJ, Cowley AW. Influence of diet and genetics on hypertension and renal disease in Dahl salt-sensitive rats. Physiol Genomics. 2004; 16:194-203. DOI: 10.1152/physiolgenomics.00151.2003 [PubMed: 14600213]

Mayorov DN. Brain angiotensin AT1 receptors as specific regulators of cardiovascular reactivity to acute psychoemotional stress. Clin Exp Pharmacol Physiol. 2011; 38:126-35. DOI: 10.1111/j. 1440-1681.2010.05469.x [PubMed: 21143493]

McCormick CM, Mathews IZ. HPA function in adolescence: role of sex hormones in its regulation and the enduring consequences of exposure to stressors. Pharmacol Biochem Behav. 2007; 86:220 33. DOI: 10.1016/j.pbb.2006.07.012 [PubMed: 16901532]

McEwen BS. Protective and damaging effects of stress mediators: central role of the brain. Dialogues Clin Neurosci. 2006; 8:367-81. [PubMed: 17290796]

McEwen BS. Stress, adaptation, and disease. Allostasis and allostatic load. Ann N Y Acad Sci. 1998; 840:33-44. [PubMed: 9629234]

McEwen BS, Nasca C, Gray JD. Stress Effects on Neuronal Structure: Hippocampus, Amygdala, and Prefrontal Cortex. Neuropsychopharmacology. 2015; 41:3-23. DOI: 10.1038/npp.2015.171 [PubMed: 26076834]

McGowan PO, Sasaki A, D’Alessio AC, Dymov S, Labonté B, Szyf M, Turecki G, Meaney MJ. Epigenetic regulation of the glucocorticoid receptor in human brain associates with childhood abuse. Nat Neurosci. 2009; 12:342-8. DOI: 10.1038/nn.2270 [PubMed: 19234457]

McMullen S, Langley-Evans SC. Maternal low-protein diet in rat pregnancy programs blood pressure through sex-specific mechanisms. Am J Physiol Regul Integr Comp Physiol. 2005; 288:R85-90. DOI: 10.1152/ajpregu.00435.2004 [PubMed: 15374820]

Miller AL, Clifford C, Sturza J, Rosenblum K, Vazquez DM, Kaciroti N, Lumeng JC. Blunted cortisol response to stress is associated with higher body mass index in low-income preschool-aged 
children. Psychoneuroendocrinology. 2013; 38:2611-7. DOI: 10.1016/j.psyneuen.2013.06.014 [PubMed: 23849598]

Miller GE, Chen E, Parker KJ. Psychological stress in childhood and susceptibility to the chronic diseases of aging: moving toward a model of behavioral and biological mechanisms. Psychol Bull. 2011; 137:959-97. DOI: 10.1037/a0024768 [PubMed: 21787044]

Milner P, Loesch A, Burnstock G. Endothelin immunoreactivity and mRNA expression in sensory and sympathetic neurones following selective denervation. Int J Dev Neurosci. 2000; 18:727-34. [PubMed: 11154842]

Misra DP, Straughen JK, Slaughter-Acey JC. Allostatic load and health: Can perinatal epidemiology lead the way forward? Paediatr Perinat Epidemiol. 2013; 27:507-8. DOI: 10.1111/ppe.12092 [PubMed: 24117491]

Mizuno M, Siddique K, Baum M, Smith Sa. Prenatal programming of hypertension induces sympathetic overactivity in response to physical stress. Hypertension. 2013; 61:180-6. DOI: 10.1161/HYPERTENSIONAHA.112.199356 [PubMed: 23150514]

Moritz KM, Dodic M, Wintour EM. Kidney development and the fetal programming of adult disease. Bioessays. 2003; 25:212-20. DOI: 10.1002/bies.10240 [PubMed: 12596225]

Munck A, Guyre PM, Holbrook NJ. Physiological functions of glucocorticoids in stress and their relation to pharmacological actions. Endocr Rev. 1984; 5:25-44. DOI: 10.1210/edrv-5-1-25 [PubMed: 6368214]

Murgatroyd C, Patchev AV, Wu Y, Micale V, Bockmühl Y, Fischer D, Holsboer F, Wotjak CT, Almeida OFX, Spengler D. Dynamic DNA methylation programs persistent adverse effects of early-life stress. Nat Neurosci. 2009; 12:1559-66. DOI: 10.1038/nn.2436 [PubMed: 19898468]

Murgatroyd C, Spengler D. Epigenetics of early child development. Front psychiatry. 2011; 2:16.doi: 10.3389/fpsyt.2011.00016 [PubMed: 21647402]

National Scientific Council on the Developing Child. Young children develop in an environment of relationships, Young Children. 2004; doi: 10.1111/j.1151-2916.1918.tb17232.x

Navar LG. The kidney in blood pressure regulation and development of hypertension. Med Clin North Am. 1997; 81:1165-1198. [PubMed: 9308604]

Nishi M, Horii-Hayashi N, Sasagawa T, Matsunaga W. Effects of early life stress on brain activity: implications from maternal separation model in rodents. Gen Comp Endocrinol. 2013; 181:3069. DOI: 10.1016/j.ygcen.2012.09.024 [PubMed: 23032077]

Oikonen M, Tikkanen E, Juhola J, Tuovinen T, Seppälä I, Juonala M, Taittonen L, Mikkilä V, Kähönen M, Ripatti S, Viikari J, Lehtimäki T, Havulinna AS, Kee F, Newton-Cheh C, Peltonen L, Schork NJ, Murray SS, Berenson GS, Chen W, Srinivasan SR, Salomaa V, Raitakari OT. Genetic variants and blood pressure in a population-based cohort: the Cardiovascular Risk in Young Finns study. Hypertension. 2011; 58:1079-85. DOI: 10.1161/HYPERTENSIONAHA.111.179291 [PubMed: 22025373]

Ojeda NB, Johnson WR, Dwyer TM, Alexander BT. Early renal denervation prevents development of hypertension in growth-restricted offspring. Clin Exp Pharmacol Physiol. 2007; 34:1212-6. DOI: 10.1111/j.1440-1681.2007.04754.x [PubMed: 17880379]

Ortiz LA, Quan A, Weinberg A, Baum M. Effect of prenatal dexamethasone on rat renal development. Kidney Int. 2001; 59:1663-9. DOI: 10.1046/j.1523-1755.2001.0590051663.x [PubMed: 11318936]

Ortiz LA, Quan A, Zarzar F, Weinberg A, Baum M. Prenatal dexamethasone programs hypertension and renal injury in the rat. Hypertension. 2003; 41:328-34. [PubMed: 12574103]

Osborn JW, Jacob F, Guzman P. A neural set point for the long-term control of arterial pressure: beyond the arterial baroreceptor reflex. Am J Physiol Regul Integr Comp Physiol. 2005; 288:R846-R855. DOI: 10.1152/ajpregu.00474.2004 [PubMed: 15793038]

Ozbay F, Fitterling H, Charney D, Southwick S. Social support and resilience to stress across the life span: A neurobiologic framework. Curr Psychiatry Rep. 2008; doi: 10.1007/s11920-008-0049-7

Parrish C, Surkan PJ, Martins SS, Gattaz WF, Andrade LH, Viana MC. Childhood adversity and adult onset of hypertension and heart disease in São Paulo, Brazil. Prev Chronic Dis. 2013; 10:E205.doi: 10.5888/pcd10.130193 [PubMed: 24309093] 
Pervanidou P, Chrousos GP. Stress and obesity/metabolic syndrome in childhood and adolescence. Int J Pediatr Obes. 2011; 6(Suppl 1):21-28. DOI: 10.3109/17477166.2011.615996

Pham TD, MacLennan NK, Chiu CT, Laksana GS, Hsu JL, Lane RH. Uteroplacental insufficiency increases apoptosis and alters p53 gene methylation in the full-term IUGR rat kidney. Am J Physiol Regul Integr Comp Physiol. 2003; 285:R962-70. DOI: 10.1152/ajpregu.00201.2003 [PubMed: 12869365]

Pote W, Tagwireyi D, Chinyanga HM, Musara C, Nyandoro G, Chifamba J, Nkomozepi P. Cardiovascular effects of Boophone disticha aqueous ethanolic extract on early maternally separated BALB/C mice. J Ethnopharmacol. 2013; 148:379-85. DOI: 10.1016/j.jep.2013.03.001 [PubMed: 23603554]

Prodam F, Ricotti R, Agarla V, Parlamento S, Genoni G, Balossini C, Walker GE, Aimaretti G, Bona G, Bellone S. High-end normal adrenocorticotropic hormone and cortisol levels are associated with specific cardiovascular risk factors in pediatric obesity: a cross-sectional study. BMC Med. 2013; 11:44.doi: 10.1186/1741-7015-11-44 [PubMed: 23425018]

Provencher PH, Saltis J, Funder JW. Glucocorticoids but not mineralocorticoids modulate endothelin-1 and angiotensin II binding in SHR vascular smooth muscle cells. J Steroid Biochem Mol Biol. 1995; 52:219-25. [PubMed: 7696142]

Radley JJ, Sawchenko PE. A common substrate for prefrontal and hippocampal inhibition of the neuroendocrine stress response. J Neurosci. 2011; 31:9683-95. DOI: 10.1523/JNEUROSCI. 6040-10.2011 [PubMed: 21715634]

Rahman I, Humphreys K, Bennet AM, Ingelsson E, Pedersen NL, Magnusson PKE. Clinical depression, antidepressant use and risk of future cardiovascular disease. Eur J Epidemiol. 2013; 28:589-95. DOI: 10.1007/s10654-013-9821-z [PubMed: 23836399]

Randall DC, Brown DR, Brown LV, Kilgore JM. Sympathetic nervous activity and arterial blood pressure control in conscious rat during rest and behavioral stress. Am J Physiol. 1994; 267:R1241-9. [PubMed: 7977851]

Raposa EB, Bower JE, Hammen CL, Najman JM, Brennan PA. A developmental pathway from early life stress to inflammation: the role of negative health behaviors. Psychol Sci. 2014; 25:1268-74. DOI: 10.1177/0956797614530570 [PubMed: 24760142]

Reich P, DeSilva RA, Lown B, Murawski BJ. Acute psychological disturbances preceding lifethreatening ventricular arrhythmias. JAMA. 1981; 246:233-5. [PubMed: 7241762]

Reynolds RM. Glucocorticoid excess and the developmental origins of disease: two decades of testing the hypothesis--2012 Curt Richter Award Winner. Psychoneuroendocrinology. 2013; 38:1-11. DOI: 10.1016/j.psyneuen.2012.08.012 [PubMed: 22998948]

Reynolds S, Lane SJ, Richards L. Using animal models of enriched environments to inform research on sensory integration intervention for the rehabilitation of neurodevelopmental disorders. $\mathbf{J}$ Neurodev Disord. 2010; 2:120-32. DOI: 10.1007/s11689-010-9053-4 [PubMed: 22127899]

Romans S, Belaise C, Martin J, Morris E, Raffi A. Childhood abuse and later medical disorders in women. An epidemiological study. Psychother Psychosom. n.d; 71:141-50. 56281. [PubMed: 12021556]

Roque A, Ochoa-Zarzosa A, Torner L. Maternal separation activates microglial cells and induces an inflammatory response in the hippocampus of male rat pups, independently of hypothalamic and peripheral cytokine levels. Brain Behav Immun. 2015; doi: 10.1016/j.bbi.2015.09.017

Roth TL, David Sweatt J. Annual Research Review: Epigenetic mechanisms and environmental shaping of the brain during sensitive periods of development. J Child Psychol Psychiatry. 2011; 52:398-408. DOI: 10.1111/j.1469-7610.2010.02282.x [PubMed: 20626526]

Ruo B, Rumsfeld JS, Hlatky MA, Liu H, Browner WS, Whooley MA. Depressive symptoms and health-related quality of life: the Heart and Soul Study. JAMA. 2003; 290:215-21. DOI: 10.1001/ jama.290.2.215 [PubMed: 12851276]

Russo SJ, Murrough JW, Han MH, Charney DS, Nestler EJ. Neurobiology of resilience. Nat Neurosci. 2012; 15:1475-84. DOI: 10.1038/nn.3234 [PubMed: 23064380]

Saez F, Castells MT, Zuasti A, Salazar F, Reverte V, Loria A, Salazar FJ. Sex differences in the renal changes elicited by angiotensin II blockade during the nephrogenic period. Hypertension. 2007; 49:1429-35. DOI: 10.1161/HYPERTENSIONAHA.107.087957 [PubMed: 17404180] 
Samuelsson AM, Clark J, Rudyk O, Shattock MJ, Bae SE, South T, Pombo J, Redington K, Uppal E, Coen CW, Poston L, Taylor PD. Experimental hyperleptinemia in neonatal rats leads to selective leptin responsiveness, hypertension, and altered myocardial function. Hypertension. 2013; 62:627-633. DOI: 10.1161/HYPERTENSIONAHA.111.00691 [PubMed: 23836797]

Sanders BJ, Anticevic A. Maternal separation enhances neuronal activation and cardiovascular responses to acute stress in borderline hypertensive rats. Behav Brain Res. 2007; 183:25-30. DOI: 10.1016/j.bbr.2007.05.020 [PubMed: 17604851]

Sapolsky RM, Meaney MJ. Maturation of the adrenocortical stress response: neuroendocrine control mechanisms and the stress hyporesponsive period. Brain Res. 1986; 396:64-76. [PubMed: 3011218]

Schmidt MV, Schmidt M, Levine S, Oitzl MS, van der Mark M, Müller MB, Holsboer F, de Kloet ER. Glucocorticoid receptor blockade disinhibits pituitary-adrenal activity during the stress hyporesponsive period of the mouse. Endocrinology. 2005; 146:1458-64. DOI: 10.1210/en. 2004-1042 [PubMed: 15591147]

Schmidt MV, Wang XD, Meijer OC. Early life stress paradigms in rodents: potential animal models of depression? Psychopharmacology (Berl). 2011; 214:131-40. DOI: 10.1007/s00213-010-2096-0 [PubMed: 21086114]

Sequeira Lopez ML, Gomez RA. The role of angiotensin II in kidney embryogenesis and kidney abnormalities. Curr Opin Nephrol Hypertens. 2004; 13:117-122. DOI: 10.1097/01.mnh. 0000109591.66112.0e [PubMed: 15090868]

Shi H, Clegg DJ. Sex differences in the regulation of body weight. Physiol Behav. 2009; 97:199-204. DOI: 10.1016/j.physbeh.2009.02.017 [PubMed: 19250944]

Shonkoff JP, Garner AS. The lifelong effects of early childhood adversity and toxic stress. Pediatrics. 2012; 129:e232-46. DOI: 10.1542/peds.2011-2663 [PubMed: 22201156]

Slopen N, Koenen KC, Kubzansky LD. Childhood adversity and immune and inflammatory biomarkers associated with cardiovascular risk in youth: a systematic review. Brain Behav Immun. 2012; 26:239-50. DOI: 10.1016/j.bbi.2011.11.003 [PubMed: 22138616]

Smith C, Carlson BE. Stress, Coping, and Resilience in Children and Youth. Soc Serv Rev. 1997; doi: $10.1086 / 604249$

Smith SM, Vale WW. The role of the hypothalamic-pituitary-adrenal axis in neuroendocrine responses to stress. Dialogues Clin Neurosci. 2006; 8:383-95. [PubMed: 17290797]

Spartano NL, Augustine JA, Lefferts WK, Gump BB, Heffernan KS. The relationship between carotid blood pressure reactivity to mental stress and carotid intima-media thickness. Atherosclerosis. 2014; 236:227-9. DOI: 10.1016/j.atherosclerosis.2014.07.014 [PubMed: 25099945]

Spieker LE, Hürlimann D, Ruschitzka F, Corti R, Enseleit F, Shaw S, Hayoz D, Deanfield JE, Lüscher TF, Noll G. Mental stress induces prolonged endothelial dysfunction via endothelin-A receptors. Circulation. 2002; 105:2817-2820. DOI: 10.1161/01.CIR.0000021598.15895.34 [PubMed: 12070106]

Stanton ME, Gutierrez YR, Levine S. Maternal deprivation potentiates pituitary-adrenal stress responses in infant rats. Behav Neurosci. 1988; 102:692-700. [PubMed: 3196438]

Steptoe A, Dockray S, Wardle J. Positive affect and psychobiological processes relevant to health. J Pers. 2009; 77:1747-76. DOI: 10.1111/j.1467-6494.2009.00599.x [PubMed: 19796062]

Sterling P, Eyer J. Biological basis of stress-related mortality. Soc Sci Med E. 1981; 15:3-42. [PubMed: 7020084]

Su S, Wang X, Kapuku GK, Treiber FA, Pollock DM, Harshfield GA, McCall WV, Pollock JS. Adverse childhood experiences are associated with detrimental hemodynamics and elevated circulating endothelin-1 in adolescents and young adults. Hypertension. 2014; 64:201-7. DOI: 10.1161/HYPERTENSIONAHA.113.02755 [PubMed: 24777980]

Su S, Wang X, Pollock JS, Treiber FA, Xu X, Snieder H, McCall WV, Stefanek M, Harshfield GA. Adverse childhood experiences and blood pressure trajectories from childhood to young adulthood: the Georgia stress and Heart study. Circulation. 2015; 131:1674-81. DOI: 10.1161/ CIRCULATIONAHA.114.013104 [PubMed: 25858196]

Neurosci Biobehav Rev. Author manuscript; available in PMC 2018 March 01. 
Taniyama Y, Griendling KK. Reactive oxygen species in the vasculature: molecular and cellular mechanisms. Hypertension. 2003; 42:1075-81. DOI: 10.1161/01.HYP.0000100443.09293.4F [PubMed: 14581295]

Treiber FA, Jackson RW, Davis H, Pollock JS, Kapuku G, Mensah GA, Pollock DM. Racial differences in endothelin-1 at rest and in response to acute stress in adolescent males. Hypertension. 2000; 35:722-725. DOI: 10.1161/01.HYP.35.3.722 [PubMed: 10720585]

Trombini M, Hulshof HJ, Graiani G, Carnevali L, Meerlo P, Quaini F, Sgoifo A. Early maternal separation has mild effects on cardiac autonomic balance and heart structure in adult male rats. Stress. 2012; 15:457-470. DOI: 10.3109/10253890.2011.639414 [PubMed: 22085295]

Tufro, a, Norwood, VF., Carey, RM., Gomez, Ra. Vascular endothelial growth factor induces nephrogenesis and vasculogenesis. J Am Soc Nephrol. 1999; 10:2125-2134. [PubMed: 10505689]

Uchida S, Hara K, Kobayashi A, Funato H, Hobara T, Otsuki K, Yamagata H, McEwen BS, Watanabe Y. Early life stress enhances behavioral vulnerability to stress through the activation of REST4mediated gene transcription in the medial prefrontal cortex of rodents. J Neurosci. 2010; 30:15007-18. DOI: 10.1523/JNEUROSCI.1436-10.2010 [PubMed: 21068306]

Vaiserman AM. Epigenetic programming by early-life stress: Evidence from human populations. Dev Dyn. 2014; doi: 10.1002/dvdy.24211

Varese F, Smeets F, Drukker M, Lieverse R, Lataster T, Viechtbauer W, Read J, van Os J, Bentall RP. Childhood adversities increase the risk of psychosis: a meta-analysis of patient-control, prospective- and cross-sectional cohort studies. Schizophr Bull. 2012; 38:661-71. DOI: 10.1093/ schbul/sbs050 [PubMed: 22461484]

Weaver ICG, Cervoni N, Champagne FA, D’Alessio AC, Sharma S, Seckl JR, Dymov S, Szyf M, Meaney MJ. Epigenetic programming by maternal behavior. Nat Neurosci. 2004; 7:847-54. DOI: 10.1038/nn1276 [PubMed: 15220929]

Weder N, Zhang H, Jensen K, Yang BZ, Simen A, Jackowski A, Lipschitz D, Douglas-Palumberi H, Ge M, Perepletchikova F, O’Loughlin K, Hudziak JJ, Gelernter J, Kaufman J. Child abuse, depression, and methylation in genes involved with stress, neural plasticity, and brain circuitry. $\mathbf{J}$ Am Acad Child Adolesc Psychiatry. 2014; 53:417-24. e5. DOI: 10.1016/j.jaac.2013.12.025 [PubMed: 24655651]

Woods LL, Weeks DA, Rasch R. Programming of adult blood pressure by maternal protein restriction: role of nephrogenesis. Kidney Int. 2004; 65:1339-48. DOI: 10.1111/j.1523-1755.2004.00511.x [PubMed: 15086473]

Woolley CS, Gould E, McEwen BS. Exposure to excess glucocorticoids alters dendritic morphology of adult hippocampal pyramidal neurons. Brain Res. 1990; 531:225-31. [PubMed: 1705153]

Yang BZ, Zhang H, Ge W, Weder N, Douglas-Palumberi H, Perepletchikova F, Gelernter J, Kaufman J. Child abuse and epigenetic mechanisms of disease risk. Am J Prev Med. 2013; 44:101-7. DOI: 10.1016/j.amepre.2012.10.012 [PubMed: 23332324]

Zanca RM, Braren SH, Maloney B, Schrott LM, Luine VN, Serrano PA. Environmental Enrichment Increases Glucocorticoid Receptors and Decreases GluA2 and Protein Kinase M Zeta (PKMS) Trafficking During Chronic Stress: A Protective Mechanism? Front Behav Neurosci. 2015; 9:303.doi: 10.3389/fnbeh.2015.00303 [PubMed: 26617502]

Zicha J, Dobešová Z, Kuneš J, Vaněčková I. Chronic endothelin A receptor blockade attenuates contribution of sympathetic nervous system to salt hypertension development in adult but not in young Dahl rats. Acta Physiol. 2012; 205:124-132. DOI: 10.1111/j.1748-1716.2012.02395.x 


\section{Highlights}

- $\quad$ Early life stress (ELS) can overwhelm an individual's capacity to adapt to a stressor, thus leading to harmful effects on the cardiovascular system in adulthood. Cohort studies have demonstrated a strong link between ELS experiences and cardiovascular disease.

- $\quad$ Toxic stress defined as "the excessive or prolonged activation of physiologic stress response systems in the absence of buffering protection afforded by stable responsive relationships" includes poverty, physical and sexual abuse, neglect, neighborhood violence, or the substance abuse or mental illness of a caregiver.

- Maternal separation (MatSep) is a well-established animal model of ELS and provides a paradigm to test the correlation between ELS and cardiovascular disease

- Among the mechanisms contributing to ELS-induced cardiovascular dysfunction, this review outlines the central nervous system (CNS); the Hypothalamic-Pituitary-Adrenal (HPA) axis; and the sympathetic nervous system (SNS), the renin-angiotensin-aldosterone system (RAAS) and the immune system.

- We conclude that ELS emerges as an independent risk factor for cardiovascular disease. This review reveals the need for further investigation in the ELS-induced mechanisms underlying future risk of premature CVD morbidity and mortality. 


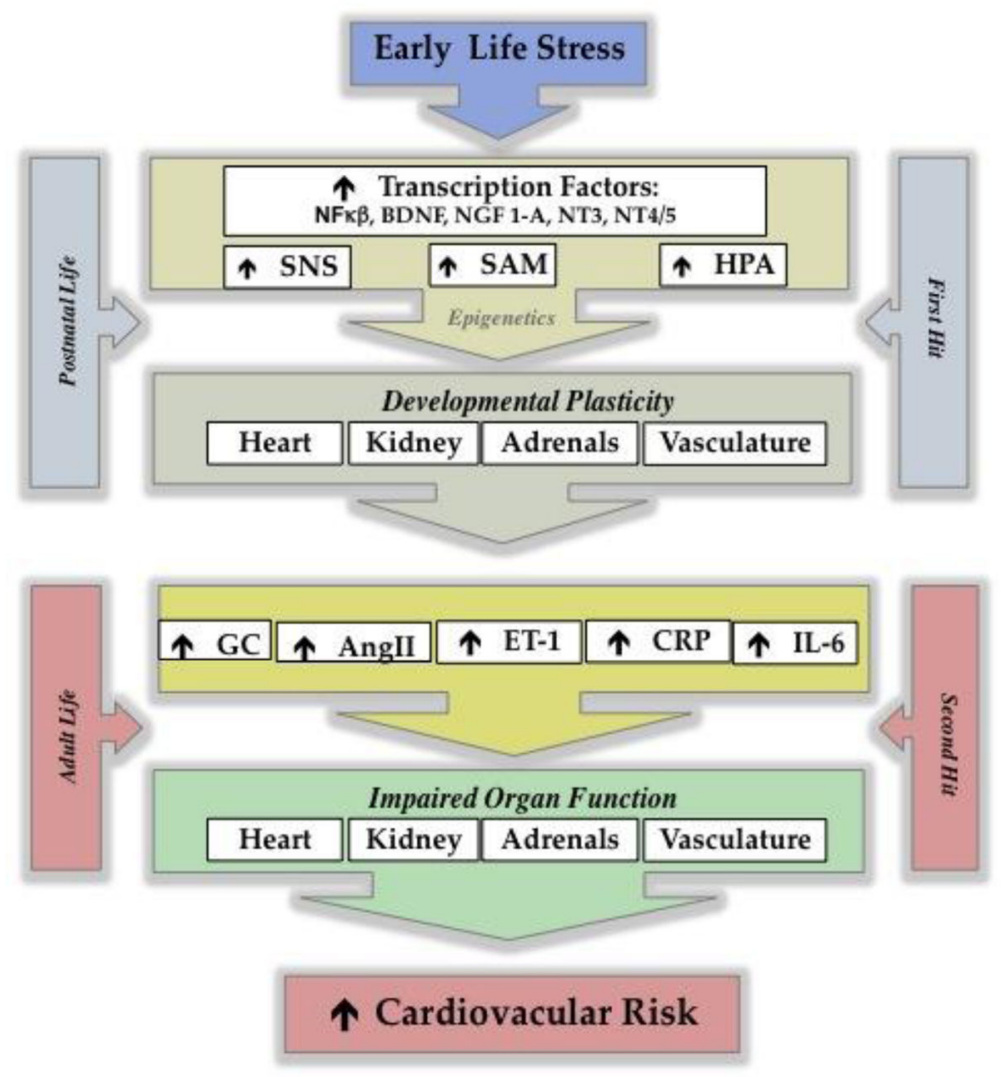

Figure 1.

Impact of ELS on the normal development of tissues and organs. During postnatal life, the exposure to a "first hit" influences the future sensitivity to a "second hit". As a result, several components of the cardiovascular system display an enhanced reactivity, leading to a greater risk to develop cardiovascular disease.

SNS=sympathetic nervous system; SAM=sympathomedullary pathway; HPA:

Hypothalamic- Pituitary-Adrenal Axis; NF-KB: nuclear factor kappa-light-chain-enhancer of activated B cells BDNF:Brain-derived neurotrophic factor NGF 1-A: Nerve growth factor-induced protein A; NT3: neurotrophin-3 NT4/5: neurotrophin-4, neurotrophin-5, GC: glucocorticoid; AngII: angiotensin II; ET-1: endothelin-1; CRP: C-reactive protein; IL-6: interleukin-6 


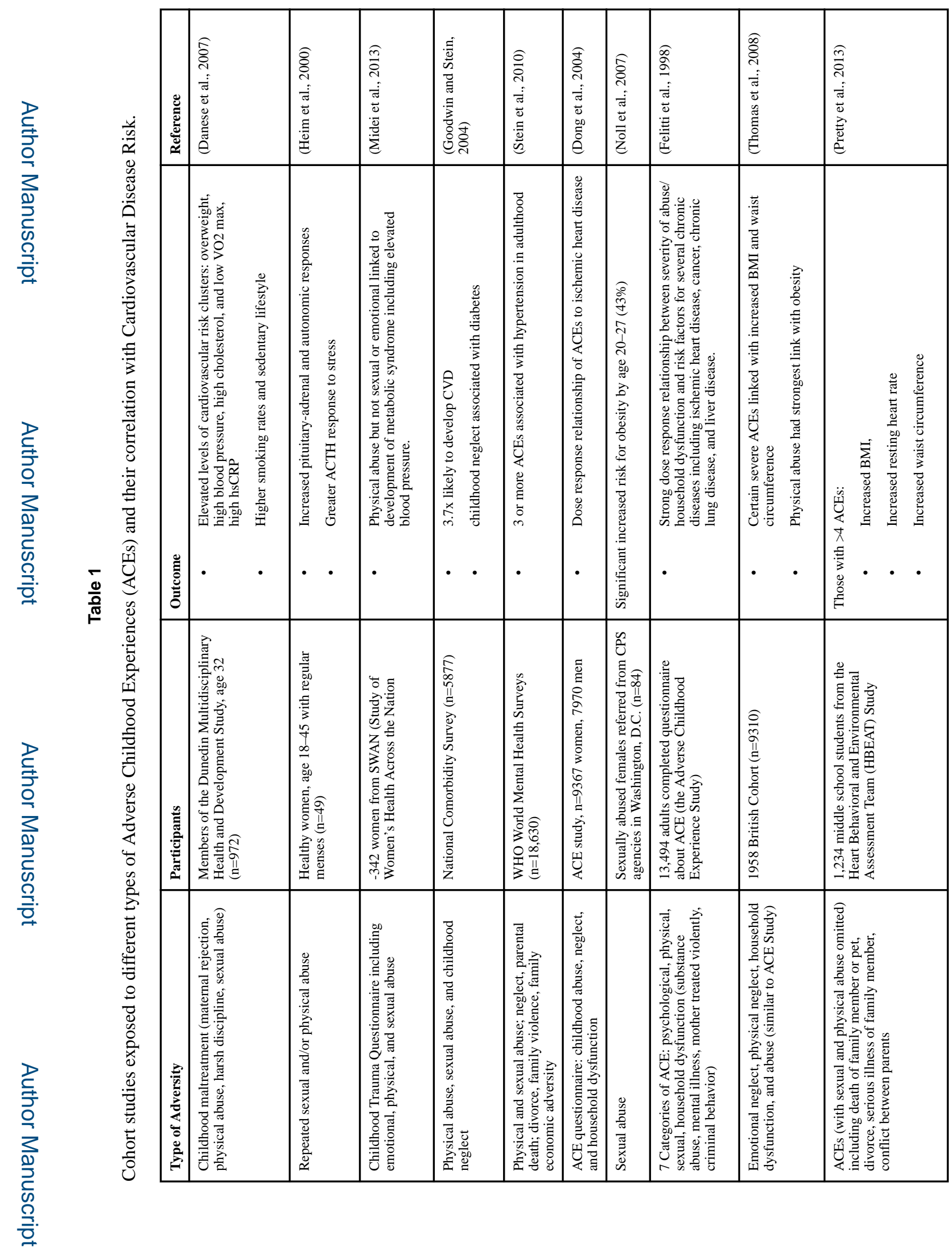

Neurosci Biobehav Rev. Author manuscript; available in PMC 2018 March 01. 


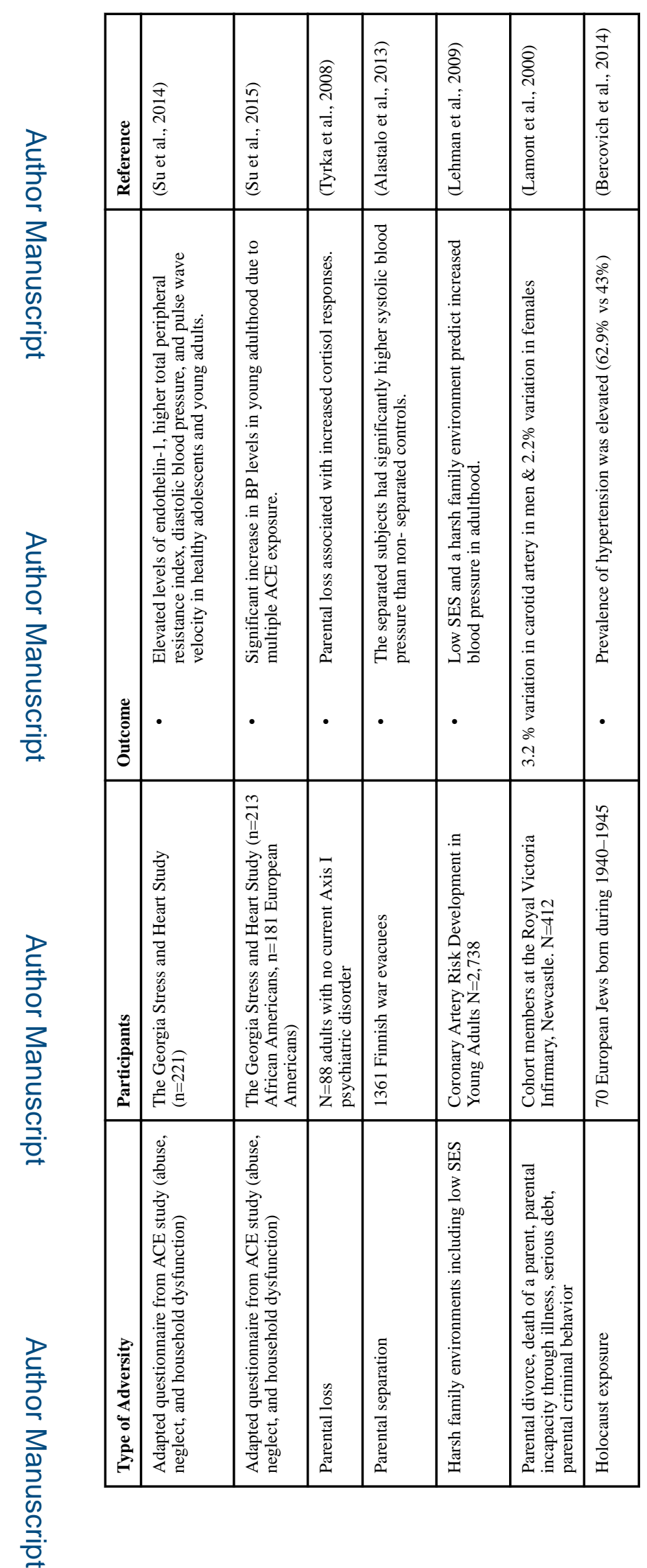

Neurosci Biobehav Rev. Author manuscript; available in PMC 2018 March 01. 